Journal of Southeast Asian Studies, 49(1), pp 4-33 February 2018.

(C) The National University of Singapore, 2018 doi:10.1017/S0022463417000662

\title{
Parsi theatrical networks in Southeast Asia: The contrary case of Burma
}

\author{
Kathryn Hansen
}

\begin{abstract}
Rangoon circa 1900 was known as 'one of the best show towns in the East'. As the capital city of Burma, then ruled from Calcutta as a province of India, it was home to more Indian nationals than Burmese. In this cosmopolitan context, two vernacular arts complexes - the Parsi theatre of India and the popular zat-pwe of Burma - flourished, competed, and converged. This article documents the 55-year long engagement of Parsi theatre in Burma within the larger history of global theatrical flows in the Indian Ocean. It highlights the story of Dosabhai Hathiram, a theatre man who rooted himself in Rangoon his entire life. And it asks, why was Parsi theatre celebrated elsewhere in Southeast Asia as a vector of modernity, and yet in Burma it left scarcely a trace behind?
\end{abstract}

The history of the Parsi theatre in Burma has long been overlooked within the larger history of global theatrical flows. This article redresses the omission by documenting the Burma-based activities of Parsi theatrical troupes over a remarkably long period, some 55 years. It focuses in particular on an intriguing life story, that of actor Dosabhai Hathiram, a Bombay man who rooted himself in Rangoon for most of his career. His movements across regions, languages, and ethnic communities prompt questions of transnational engagement and impact, even as they trace the extensive theatrical circuits of Parsi theatre companies in the eastern Indian Ocean.

The emergence of global history approaches over the past two decades has been very useful to understanding the development of modern and transitional theatrical practices in South and Southeast Asia. ${ }^{1}$ The transnational circulation of Parsi theatre needs to be more widely acknowledged and contextualised within this body of literature. So far, most of the scholarship on the beginnings of modern theatre in Asia documents the transoceanic adventures of anglophone companies as they carried

Kathryn Hansen is Professor Emeritus at the University of Texas at Austin. Correspondence in connection with this paper should be addressed to: kgh@austin.utexas.edu. The author would like to thank Sabeena Gadihoke and the late Homai Vyarawalla, whose contributions are at the heart of this project; and Mitra Sharafi, Ward Keeler, Dick Eaton, Nile Green, Moe Moe Lwin, and Thurein Aung.

1 'Transitional' refers to an intermediary category between traditional and modern in Asian Theatre Studies, often associated with the period of British colonialism and 'Western' practices such as commercial companies, the proscenium stage, and the prevalence of melodrama. Hanne de Bruin's designation 'hybrid popular' is also used for this kind of theatre. See discussion in Andrew P. Killick, 'Jockeying for tradition: The checkered history of Korean Ch'angguk opera', Asian Theatre Journal 20, 1 (2003): 50. 
dramatic entertainment to ports connected along routes of trade and empire. Often troupes started from the imperial metropole and travelled eastward to enclaves eager for connection to home. ${ }^{2}$ George Norville's Our Boys' Company, for example, presented the London comedy of that name across India in the 1880s. ${ }^{3}$ Theatre impresario Daniel Bandmann took a different route, first moving from Europe to the United States, then sailing from San Francisco to Australia, New Zealand, Ceylon, India, and Burma on his tour of 1879 to $1883 .{ }^{4}$ Scholars have lately added the Australasian circuit, an independent zone of theatrical activity in the Pacific and Indian oceans. George Lewis and his actress wife, Rose Edouin, setting out from their home base in Melbourne, conducted many long tours to China, Southeast Asia, India, and Ceylon beginning in the 1860s, altering the theatrical landscape. ${ }^{5}$

Surprisingly, Asian actors too were on the move, travelling to destinations in Europe and the United States to perform in Asian languages. Kabuki stageman Kawakami made three trips to London and other Western cities at the turn of the century, whereas Chinese theatre companies ventured to California at the time of the Gold Rush. ${ }^{6}$ From India, the Urdu-speaking Balivala Victoria Theatrical Company, the most celebrated of all Parsi theatre companies, sailed to England in 1885-86. ${ }^{7}$ These counter flows, from the periphery to the centre, as it were, evoked some

2 Michael R. Booth and Pamela Heckenberg, 'Touring the empire', Essays in Theatre 6, 1 (1987): 49-60; Tobias Becker, 'Entertaining the empire: Theatrical touring companies and amateur dramatics in colonial India', Historical Journal 57, 3 (2014): 699-725.

3 The Norvilles, in addition to playing at the Gaiety Theatre in Bombay, performed H.J. Byron's comedy 'Our Boys' in Lahore, Kanpur, and Lucknow (Times of India, 18 Oct. 1883, p. 2). On the Norvilles, see Kumudini A. Mehta, 'English drama on the Bombay stage in the late eighteenth century and in the nineteenth century', (PhD diss., University of Bombay, 1960), pp. 222-4.

4 Daniel Bandmann's memoir, An actor's tour: Or, seventy thousand miles with Shakespeare (Boston: Cupples, Upham, 1885), offers a detailed account of the lives of peripatetic actors in Asia at this time. Bandmann's performances in India were noted for their serious representation of melodrama and tragedy. D.E. Wacha, Shells from the sands of Bombay (Bombay: Bombay Chronicle Press, 1920), p. 353; Mehta, 'English drama', pp. 225-6. Bandmann's son, Maurice E. Bandmann, established an even more successful and far-reaching global theatre network in the early 1900s. Christopher B. Balme, 'The Bandmann circuit: Theatrical networks in the first age of globalization', Theatre Research International 40, 1 (2015): 19-36.

5 Desley Deacon, 'Location! Location! Location! Mind maps and theatrical circuits in Australian transnational history', History Australia 5, 3 (2008): 81.1-16; Mimi Colligan, Circus and stage: The theatrical adventures of Rose Edouin and G.B.W. Lewis (Clayton: Monash University Publishing, 2013). George Lewis built the Lyceum Theatre and the Theatre Royal in the heart of Calcutta. Rose became a mentor to Girishchandra Ghosh, the founding father of modern Bengali theatre. Perhaps the Lewises' greatest contribution was to popularise domestic melodrama, a genre that transformed into the 'social' of Indian vernacular cinema and drama. Kathryn Hansen, 'Mapping melodrama: Global theatrical circuits, Parsi theater, and the rise of the social', BioScope 7, 1 (2016): 1-30.

6 Kawakami Otojiro and his wife Sadayakko with 18 company members made three tours to the West, performing in Honolulu, San Francisco, Seattle, New York, Washington DC, London, Paris, Moscow and Stockholm. They called themselves 'The Imperial Court Theatre of Japan' (Kevin J. Wetmore, Jr, Siyuan Liu and Erin B. Mee, Modern Asian theatre and performance 1900-2000 [London: Bloomsbury, 2014], pp. 29-30). The first documented Chinese troupe to visit the United States was the Tong Hook Tong Dramatic Company, which performed in San Francisco in 1852 (Daphne Pi-Wei Lei, Operatic China: Staging Chinese identity across the Pacific [New York: Palgrave Macmillan, 2006], p. 27).

7 'The Irving of India', The Sketch, 13 Mar. 1895, p. 352. See Hansen, 'Mapping melodrama': 17, 21-2. 
curiosity, but had little effect except among diasporic communities like the overseas Chinese.

When Parsi troupes performed around the Indian Ocean, on the other hand, the results were quite different. As a striking example of Asia-to-Asia linkages, Parsi theatrical networks are in a class by themselves. For about half a century, Parsi theatre companies from Bombay mounted tours to Colombo, Rangoon, Penang, Singapore, Surabaya, and Batavia. ${ }^{8}$ The popularity of Parsi theatre was unprecedented in its heyday. A hybrid style incorporating European, West Asian, and South Asian elements, Parsi theatre appealed to audiences across a wide geographic swathe.

Reports of the avid reception by local audiences abound, despite differences of language and ethnicity. Wilmot Wijetunge recalls the reception in Colombo:

Gorgeous and scintillating constumes [sic], colourful and artistic scenaries [sic] before brilliant kerosene-oil footlights, breath-taking spectacular mechanical devices (of marble palaces floating up into thin air and of wondrous magic treasure caves), rapid dramatic sequences grasped in spite of a foreign language.

In particular, the irresistible music of the theatre operated as an agent of intracultural seduction:

... and above all, the haunting airs of the music of North India - all these fascinated and captivated the onlooker. ${ }^{9}$

Due to its sophistication and charm, Parsi theatre as it travelled was copied and adapted into local languages and genres. In Ceylon, Sinhala-language scripts were set to melodies from the Parsi theatre, and the new form of theatre was christened Nurthi. ${ }^{10}$ Singapore, Penang, and other cities to the east were visited by Parsi companies in the 1870s, leading to 'imitation Parsi theatre' (wayang parsi tiruan). This intermediary form evolved into Bangsawan, the first of the modern genres of Malay theatre. ${ }^{11}$ To the west, in Yemen the modern theatre similarly traces its roots to the visit of a theatrical troupe from India, most likely a Parsi company. ${ }^{12}$ Such was the sway of Parsi theatre that it left an enduring impact on global theatrical culture.

This project aims to supplement current knowledge of Parsi theatrical circuits by bringing to the fore the case of colonial Burma. Rangoon was a thriving hub of world

8 Kathryn Hansen, Stages of life: Indian theatre autobiographies (London: Anthem, 2011); Somnath Gupt, The Parsi theatre: Its origins and development, ed. and trans. Kathryn Hansen (Calcutta: Seagull, 2005); Matthew Isaac Cohen, The Komedie Stamboel: Popular theater in colonial Indonesia (Athens: Ohio University Press, 2006); Matthew Isaac Cohen, 'On the origin of the Komedie Stamboel: Popular culture, colonial society, and the Parsi theatre movement', Bijdragen tot de Taal-, Land- en Volkenkunde 157, 2 (2001): 313-57; Jan van der Putten, 'Bangsawan: The coming of a Malay popular theatrical form', Indonesia and the Malay World 42, 123 (2014): 268-85.

9 Wilmot P. Wijetunge, 'The story of the Sinhalese drama', Ceylon Observer, 9 July 1944, p. 8. Cited in E.R. Sarachchandra, The folk drama of Ceylon (Ceylon: Government Press, 1952/1966), p. 131.

10 Garrett M. Field, 'Music for inner domains: Sinhala song and the Arya and Hela schools of cultural nationalism in colonial Sri Lanka', Journal of Asian Studies 73, 4 (2014): 1045.

11 Matthew Isaac Cohen, 'Border crossings: Bangsawan in the Netherlands Indies in the nineteenth and early twentieth centuries', Indonesia and the Malay World 30, 87 (2002): 102-3.

12 Sa'id 'Aulaqi, Saba'un 'aman min al-masrah fi-'l-yaman [Seventy years of theatre in Yemen] (Aden: South Yemen Ministry of Information and Culture, 1981/1983), pp. 13-16. Unpublished translation from the Arabic by Katherine Hennessey, to whom many thanks. 
entertainment, 'one of the best show towns in the East', circa $1900 .{ }^{13}$ It was home to the Jubilee Hall, a well-appointed theatre that seated nearly 800 patrons (see fig. 7), as well as hotel ballrooms, clubs, and cabarets. Theatre, opera, ballet, and circus professionals regularly stopped in Burma on their tours out of Europe, Australia, and the United States. This terrain was also frequented by artists from India, notably the Parsi theatre companies that called around the Indian Ocean.

The principal objective of this article is to track the movements of Parsi theatre companies into Burma in the late nineteenth and early twentieth centuries. It is noteworthy that these visits predated the establishment of British rule over Upper Burma. Balivala and his famed Victoria Company made a number of visits to the court of King Thibaw in Mandalay even before the Third Anglo-Burmese War of 1885. With the massive influx of Indians following annexation, Rangoon became so hospitable for Indian actors that some made it their permanent home. Parsi actor-director Dosabhai Hathiram spent most of his life in Burma, using it as a base for travel further to the east.

Hathiram's story gives an individual face and voice to the connected histories emerging from this period. His life narrative holds particular value for understanding how global networks of commercial theatre shaped groups and individuals during colonial times. Highlighting person-centred data within densely woven contexts of culture and history is a method I have utilised before. In my book Stages of life: Indian theatre autobiographies, I presented the narratives of four actors and poets who authored their own accounts of life in the Parsi theatre. These texts shed much light on the history of theatre as an institution, cultural formations during the rise of nationalism, oral systems of knowledge, and the social and emotional worlds of performing communities. ${ }^{14}$

Dosabhai Hathiram, as far as we know, did not compose an autobiography, but his biography may be assembled from several discrete archives: official records, family memorabilia, and newspaper reports. Following Hathiram as he moved across geographical areas, linguistic zones, and community boundaries promises to reconfigure our knowledge of theatrical circuits in the Indian Ocean. It extends the significance of particular nodal points, positioning them in a network of linkages across a larger intercolonial landscape.

While this article locates Burma with some specificity within maritime networks of exchange, it also takes up the question of intracultural contact. What can be learned about the impress of Parsi theatre on the distinctive performative heritage of Burma? Did the Parsi companies function as agents of artistic change there as they did elsewhere? Does the case fit the model of transmission by which innovation and modernity flowed from metropole to periphery? My review finds the Burma case to be an anomaly. There is no narrative of imitation or adoption of Parsi theatre in Burma, nor is there any genre that traces its origins to Parsi company visits. The environment in Burma, I will argue, was welcoming towards Parsi theatre, but the local performing arts complex was already highly developed. For this and other reasons, Parsi theatre

13 Andrew Selth, Burma, Kipling and Western music: The riff from Mandalay (New York: Routledge, 2016), p. 181.

14 Hansen, Stages of life, pp. 36-47. 


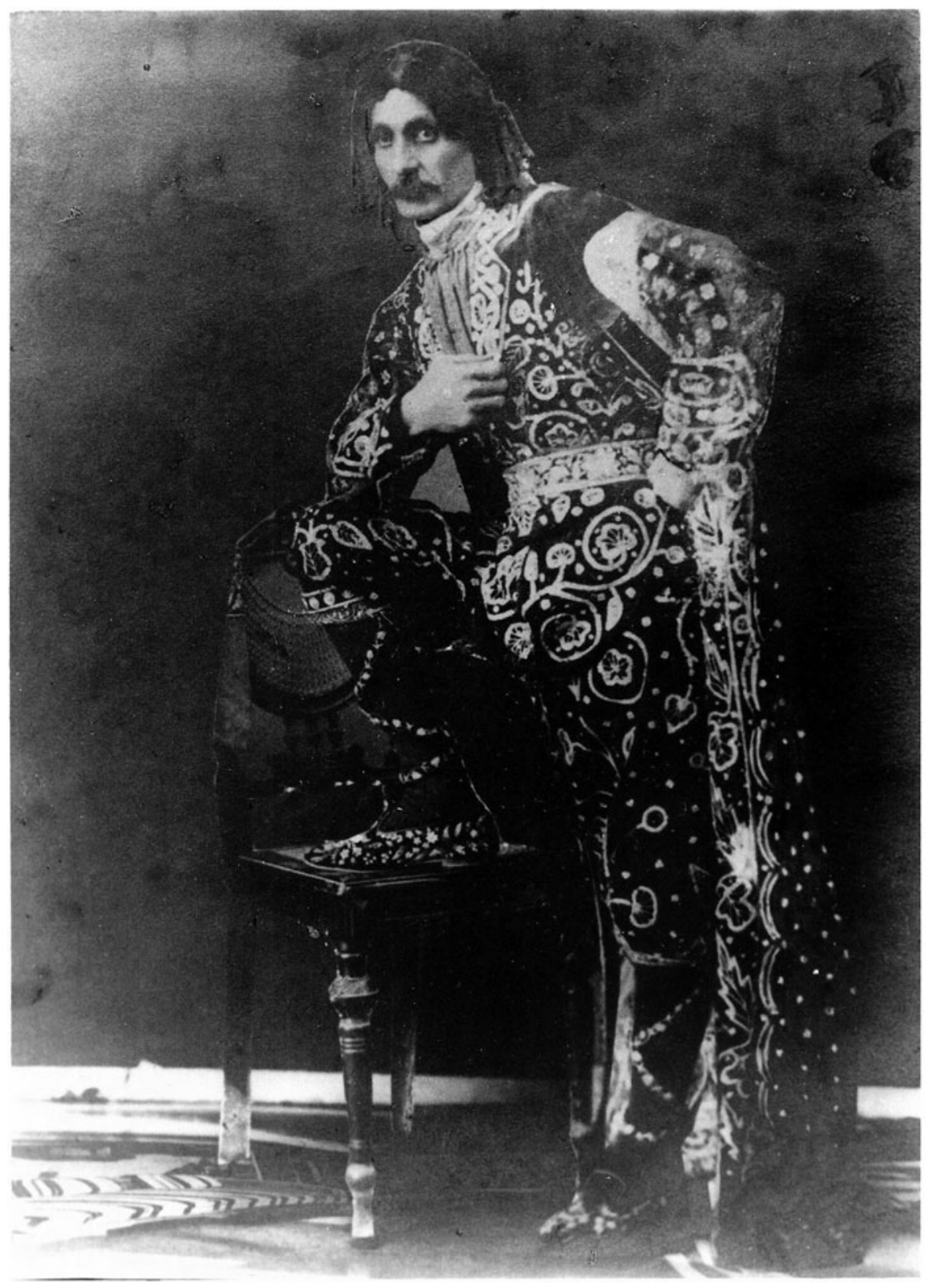

Figure 1. Dosabhai Hathiram in costume

Photograph, courtesy of the late Homai Vyarawalla. Author's collection.

could flourish for a time, yet it had little long-term effect. The conditions that led to Burmese resistance to Parsi theatre are explored in the concluding discussion. 


\section{Parsi theatre goes global}

A brief look at the development of the Parsi theatre should clarify how and why it embarked on its extraordinary global expeditions. The Parsi community descended from Iranian Zoroastrians who migrated to the area of Gujarat, India, at the end of the first millennium. Many relocated to Bombay in the eighteenth century and advanced through finance and trade. As brokers of European mercantile houses, they interacted with colonial elites and were exposed to English education. It was at the newly opened Elphinstone College that young Parsi men first took an interest in dramatics. Initially, they formed amateur clubs to experiment with play-acting and the proscenium stage. By the late 1860s, these clubs were altering into professional companies managed by Parsi businessmen. To increase revenue, the companies began extensive tours - around India by rail and then to Indian Ocean ports by sea. ${ }^{15}$

At first, the motivation for travel was the dearth of playhouses in Bombay. For several decades, a single theatre on Grant Road offered the only suitable stage. Competition to use it was fierce, and rival companies vied to rent the theatre on different nights of the week. Then invitations from India's royals lured company managers to exotic courts such as Hyderabad. With the construction of railway lines, travel across India became less arduous. Theatre companies booked special bogies and took over entire trains for their performers, luggage, trappings, and labourers. As the Parsi theatre travelled to Delhi, Calcutta, Madras and less urban locations, offshoots of the original Bombay companies sprang up. The lure of Parsi-style musical productions, rich in spectacular scenery and effects, was contagious. ${ }^{16}$

Meanwhile, global networks of commercial theatre were developing on an unprecedented scale. Performers, troupes, productions, and dramatic texts criss-crossed the seas, popularising new genres and styles. In the anglophone world, theatrical circuits connected the metropolitan centres of England, Ireland, and the United States across the Atlantic. Australia became the centre of an alternative theatre economy following the gold rushes of the 1850s. Traffic between Europe and Asia exploded with the opening of the Suez Canal. By 1870, actors setting out from London were performing in Egypt, India, Burma, China, Australia, New Zealand, the United States and Canada before heading home. ${ }^{17}$

Eager to extend their popularity and establish new markets, Parsi companies too began to explore the wider world. In Rangoon, Colombo, Penang, and Singapore, they found lucrative opportunities. Company proprietors were not daunted by the seemingly risky prospects of investing overseas. Parsi merchant princes had amassed sizeable fortunes and were looking for new frontiers by the early nineteenth century. Men like Jamsetjee Jejeebhoy, who spent the early part of his career in China in the opium trade, were attuned to the profits to be had outside India. Parsis excelled not only in business but in trades like ship-building, and oceanic travel was not prohibited to them, as it was to high-caste Hindus who were often excommunicated for going

15 For a more detailed history of the early days of the Parsi theatre, see Kathryn Hansen, 'Languages on stage: Linguistic pluralism and community formation in the nineteenth-century Parsi theatre', Modern Asian Studies 37, 2 (2003): 381-405.

16 Hansen, Stages of life, pp. 11-12; Gupt, Parsi theatre, pp. 35-6, 116-20.

17 Deacon, 'Location! Location!': 81.5. 
over the 'black water'. ${ }^{18}$ Thus it happened that Parsi entrepreneurs were obvious candidates for initiating global traffic in Indian theatre.

\section{Burma, magnet for immigrants}

It took the British three wars to subjugate resource-rich Burma with its vast endowments of teak, oil, and rubies. First, they pushed back its western frontier and then moved northward from the sea coast. Military forces completed the takeover in 1885 by removing the king, Thibaw Min, from his throne in Mandalay. Over a million Indians surged into Burma after annexation. By the early twentieth century, Indian immigration had become a flood, changing Burma forever. ${ }^{19}$

If competition within India and the search for new markets propelled moneyed interests, including theatre managers, towards port cities to the east, a number of advantages made Burma a favoured choice, particularly after its usurpation by the British. Parsi traders had been active in Burma in the eighteenth century, and steamship travel increased the frequency of contact. Rangoon became a pragmatic destination for mercantile communities such as the Parsis and Baghdadi Jews of Calcutta. The image of Burma held by many in India was as a land of riches, especially in the final years of the Konbaung dynasty. The land was the 'Wild East', India's America, where one could get rich quick. Among theatre folk, King Thibaw was famed for his love of artistic spectacle and largesse towards entertainers. His reputation as a patron of the arts was an enormous attraction for impresarios like Victoria Company actor-manager K.M. Balivala, who was to lead his Parsi theatre troupe to Mandalay multiple times.

After capturing Mandalay, the British redirected the wealth of Upper Burma southward towards Rangoon, the capital city. Already the colonial administrative centre since 1862, Rangoon was completely rebuilt and transformed into a modern metropolis. ${ }^{20}$ The influx of Indians to Rangoon was of such a magnitude that by the turn of the century Indians outnumbered Burmese in the city. Foremost among the immigrants was the capitalist class: moneylenders and traders primarily from the Parsi, Jewish, and Chettiar communities. ${ }^{21}$ Professionals, including lawyers, doctors, teachers, and administrators, formed the second group. They settled in Burma to staff the civil service, establish the educational system, and implement the colonial project of governance. A large population of migrant workers, recruited for construction jobs and plantation work, constituted a third class of resident Indians. Labourers contributed hugely to the economy, but were less significant as

18 Among orthodox Parsis, the highest level of ritual purity (as required of priests) was compromised by crossing the sea. This might render the validity of certain ceremonies as void. However, Parsis in general did not risk rejection by their community on account of travel. Mitra June Sharafi, Law and identity in colonial South Asia: Parsi legal culture, 1772-1947 (Cambridge: Cambridge University Press, 2014), pp. 287, 311.

19 Thant Myint-U, The river of lost footsteps: Histories of Burma (New York: Farrar, Straus \& Giroux, 2006), p. 185.

20 Michael W. Charney, A history of modern Burma (Cambridge: Cambridge University Press, 2009), p. 19.

21 Nalini Ranjan Chakravarti, The Indian minority in Burma: The rise and decline of an immigrant community (London: Oxford University Press for the Institute of Race Relations, 1971), p. 30. 


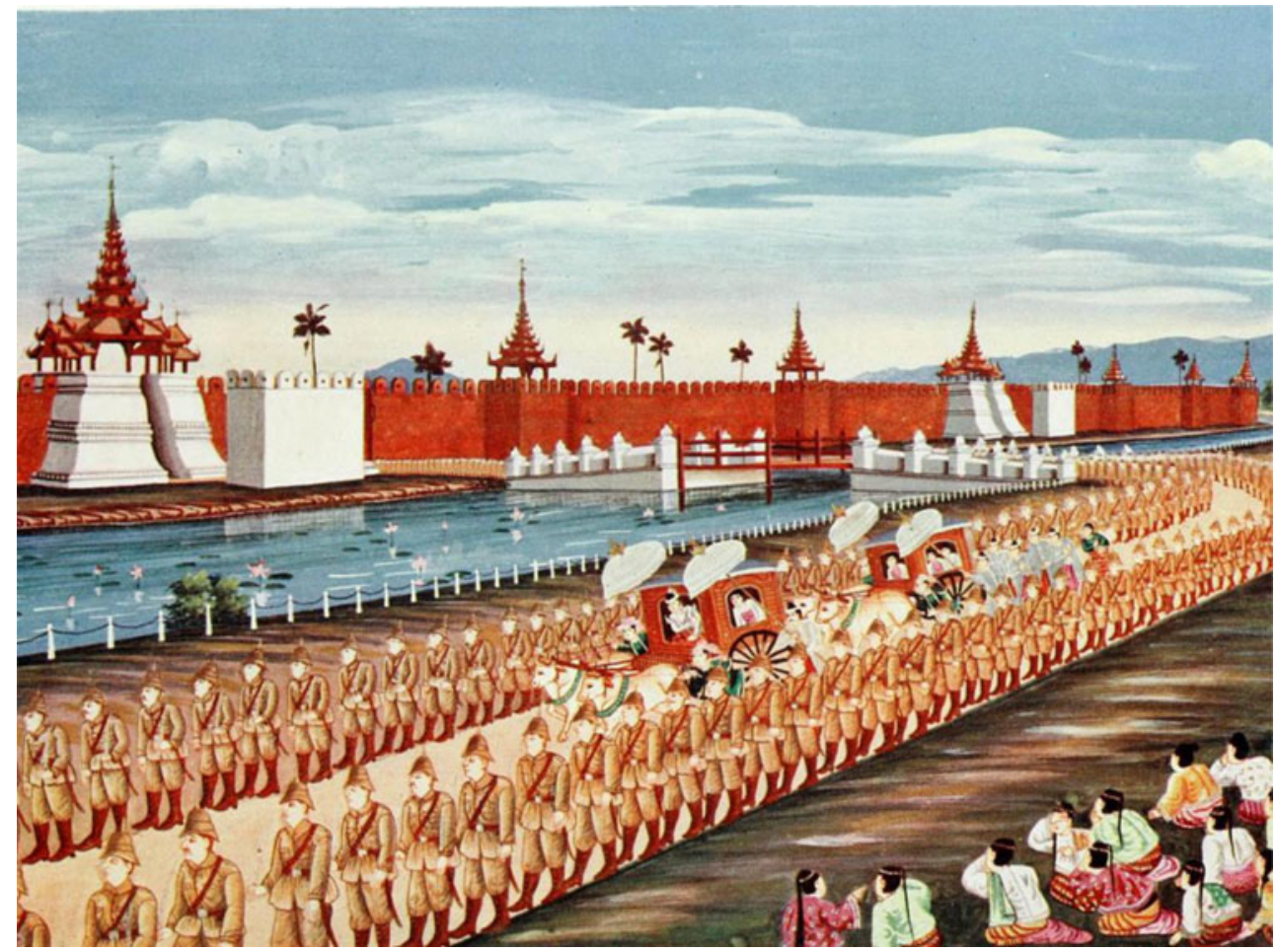

Figure 2. Saya Chone, King Thibaw leaving Mandalay; painting, 1900s Wikimedia commons.

builders of cultural institutions. ${ }^{22}$ The armed forces, comprised of Indian soldiers, police, prison guards and other enforcers, were significant too. They formed a sizeable percentage of the theatre-going audience in India, and probably played the same role in Burma.

Dr N.N. Parakh 'Rangoonwala' (1853-1935) was one Parsi professional who took up residence in Burma during the economic boom and became a community leader. He may well have facilitated Parsi theatre company tours to and within Burma, since he had himself been an actor and playwright in Bombay. He was one of the founders of the Elphinstone Theatrical Company. ${ }^{23}$ Accomplished in both male and female roles, Parakh was the company's leading actor in the early 1870s. He was known especially for his work in the popular Urdu pageant, the Indar sabha. He himself wrote two plays, Sulemani shamshir and Phalkasur salim. In 1874, he left for medical studies in England. After returning to Bombay, he decided to relocate to Rangoon to set up

22 By 1938, 2.5 million workers had gone to Burma under the kangani system of labour recruitment. Daniel Naujoks, 'Emigration, immigration, and diaspora relations in India', Migration Policy Institute, 15 Oct. 2009; http://www.migrationpolicy.org/article/emigration-immigration-and-diaspora-relationsindia (last accessed 23 Oct. 2015).

23 His father was headmaster of the Elphinstone High School, Bombay, in 1842. H.D. Darukhanawala, Parsi lustre on Indian soil, vol. II (Bombay: G. Claridge, 1963), p. 455. 
his medical practice. ${ }^{24} \mathrm{He}$ lived in Rangoon with his wife, Avabai, for many decades, becoming a pillar of the Parsi community. ${ }^{25}$

The Indian mercantile and professional classes, visible beneficiaries of British rule, were eventually to become targets of Burmese nationalist rancour. Nonetheless, in the late nineteenth and early twentieth centuries, their industry and ideas helped create a cosmopolitan order of sorts. A public sphere emerged in Rangoon, in which English education and publications together with Indian-language printing presses, newspapers, literary societies, and theatrical clubs proliferated in a pluralistic environment. ${ }^{26}$

In cities like Bombay and Calcutta, audiences for Parsi theatre shows were made up of a majority of Indian spectators together with a small number of British dignitaries representing civil and military branches. The playhouses were divided into four or five seating classes, accommodating rich and poor alike. The halls used in Burma may have been more basic than those in India, but a similar range of Indian castes and classes, from soldiers and labourers to gentry, would have prevailed, together with a sprinkling of other groups, including Burmese, Chinese, and Europeans. Businessmen, Parsis or otherwise, provided sponsorship and financial backing for these performances.

The so-called Parsi theatre was never an enterprise exclusive to Parsis, and in Burma, the number of Parsis in residence was too small to sustain that role even if such had been the case. ${ }^{27}$ Here, as in India, language was not a barrier to enjoyment by the diverse groups that made up the audience. They revelled in the singing, dancing, spectacle, and familiar stories, even when spoken dialogues were in an unfamiliar tongue. ${ }^{28}$ The reception of Parsi theatre was aided by the fact that Urdu, and even more its spoken form, Hindustani, assumed the character of a lingua franca in Burma. Although many Indian immigrants spoke Bengali and Tamil as their first languages, Urdu was used by colonial officials, Indian residents, and ordinary Burmese. A significant Muslim community also fostered education in Urdu and promoted its literary culture. ${ }^{29}$ In the polyglot environment of post-1885 Burma, the Parsi-Urdu theatre was welcomed as a distinctive Indian pastime, even as it appealed across boundaries through its attractive music and sophisticated stagecraft.

24 Gupt, Parsi theatre, pp. 31, 119, 136-8.

25 Dr N.N. Parakh's and his wife's names are listed in Parsi tombstones from Burma, transcribed from the Parsi cemetery in Rangoon by Mitra Sharafi. Avabai died in 1917; http://hosted.law.wisc. edu/wordpress/sharafi/files/2013/04/Burmese-Tombstones-as-of-8-Dec-2014.pdf (last accessed 8 May 2016).

26 Nile Green, 'Buddhism, Islam and the religious economy of colonial Burma', Journal of Southeast Asian Studies 46, 2 (2015): 182. Su Lin Lewis, 'Print culture and the new maritime frontier in Penang and Rangoon', Moussons: Recherche en sciences humaines sur l'Asie du Sud-Est 17 (2011): 131-2.

27 Mitra Sharafi cites Menant who determined that there were 300 Parsis living in Rangoon in 1912. The estimate seems low, since the total population of Rangoon in 1901 was 234,881 , and over half were of Indian origin. Mitra Sharafi, Colonial Parsis and law: A cultural history (Mumbai: K.R. Cama Oriental Institute, 2010), p. 66.

28 Late 19th-century Parsi theatre plays were composed principally in Gujarati or Urdu, with songs in varieties of Hindi such as Braj Bhasha and sometimes English. Depending on the location, additional songs and comic improvisations could be introduced in Tamil, Marathi, Bengali, or other languages. For discussion of the language shifts in the 19th-century Parsi theatre, see Hansen, 'Languages on stage'. 29 Green, 'Buddhism, Islam': 184-8. 


\section{The backdrop of Burmese performing arts}

If this period was a time of opportunity and advancement for Indians in Burma, many Burmese experienced it as quite the opposite. The British not only deprived the population of its revered indigenous kings, they eliminated the nobility and broke up hereditary networks of influence in the countryside. They substituted secular English education for traditional learning and ethical instruction imparted by Buddhist monks, undermining the moral order. Rebellion and dacoity were rampant for years, and the crime rate surged, only to be matched by an increase in policing, incarceration, and capital punishment. With the disruption of the class structure of traditional society, ethnic fissures developed. By choosing not to govern Burma through local authorities, as they attempted in India, and leaving the job to transplanted Indian surrogates, the British stoked antipathy towards Indians and themselves. These changes led to long-lasting resentment and created the conditions for a virulent strain of ethnic nationalism to emerge in the twentieth century. ${ }^{30}$

Among the losses inflicted by the British was the disruption of an elaborate system of court regulation and patronage that ensured a high level of training for classical performers of the arts. Whereas the British saw Burma's rulers as 'oriental despots' exercising tyranny over passive Burmese, historians today tell a different story. The long reign of the Konbaung dynasty (1752-1885) was a period of political integration, cultural consolidation and prosperity, ruled conjointly with the Buddhist establishment. ${ }^{31}$ Thibaw Min may have been a weak king, but he continued the cultural resurgence begun earlier, lavishing resources upon the arts. Royal support also nurtured a literati class of playwrights and promoted high standards of performance in the Burmese language. I turn now to this context, the state of Burmese drama and theatre up to 1885, which was the milieu within which Parsi theatre folk were received upon their arrival in Burma.

As early as 1795, British officials noted the superiority of Burma's theatre shows when compared to India's. Their accounts indicate that Burmese drama was prevalent not only in palaces and at houses of provincial governors, but at public festivals where large numbers of spectators gathered to enjoy free performances. ${ }^{32}$ Theatre was 'the great national amusement of the country', wrote a casual European visitor in $1896 .{ }^{33}$ 'There is no nation on the face of the earth so fond of theatrical representations as the Burmese', opined the longtime resident, Sir James George Scott. ${ }^{34}$

Zat pwe, the generic term for dramatic entertainment accompanied by music and dance, took place in the court or in the countryside, but always in the open air and on the ground, with dignitaries positioned above the actors. Puppet theatre (yokthe pwe)

30 Thant Myint-U, The making of modern Burma (Cambridge: Cambridge University Press, 2001), pp. 3-6, 240-44.

31 Victor Lieberman, Strange parallels: Southeast Asia in global context, c. 800-1830, vol. 1 (Cambridge: Cambridge University Press, 2003), pp. 173-211. Thant, The making of modern Burma, pp. 9-10, 79103.

32 Hla Pe, Konmara pya zat by U Pok Ni (London: Luzac \& Co., 1952), pp. 1-4; Noel F. Singer, Burmese dance and theatre (Kuala Lumpur: Oxford University Press, 1995), pp. 13-14.

33 Gwendolen Trench Gascoigne, Among pagodas and fair ladies: An account of a tour through Burma (London: A.D. Innes \& Co., 1896), p. 113.

34 James George Scott, The Burman: His life and notions, by Shway Yoe, 2nd ed. (London: Macmillan \& Co., 1896), p. 284. 
was also a thriving art, of even greater prestige than zat pwe in the nineteenth century. Both genres employed written scripts composed by literati poets, preserved in palm leaf manuscripts before printing became widespread in the 1870 s. With a large repertoire of texts based on the Jatakas, the Ramayana, and historical chronicles, and numerous touring troupes on the move, Burmese theatre enjoyed a high reputation and was in constant demand. It treated secular as well as religious themes. ${ }^{35}$

Burma's performing arts were not insular; they had benefited from interaction with surrounding cultures for centuries. The inputs from abroad that stimulated the greatest growth occurred between the sixteenth and eighteenth centuries. Burma's incursions into Siam led to the fall of Ayutthaya in 1767 and the capture of thousands of entertainers who were brought back to the court. A veritable renaissance ensued, as the royal centre increased its cultural authority and integrated traditions from Siam, Java, and Cambodia. ${ }^{36}$ Although open to foreign influences, the Burmese arts complex remained distinctive and resilient. In the nineteenth century, the Western piano was assimilated within Burmese classical music so thoroughly as to be given a new name, sandaya. Opaya ('opera'), a category reflecting Western influence, became one item in a full evening's pwe performance. ${ }^{37}$

Several factors outside the realm of dramatic arts contributed to the strength of the theatrical tradition. The first was the unusually high literacy rate among the male population. From the late sixteenth century, the reach of monastic networks penetrated large parts of Burma. Most village boys learned to read and write during their years as students, novices, or monks. ${ }^{38}$ Literacy enabled the advance of drama and other forms of literature by increasing knowledge of languages, respect for books, familiarity with literary conventions, and ease with textuality.

Another element that increased the prestige of theatre was the ritual significance of classical music in the royal courts. Music was part of all official ceremonies, drumming being especially prized for its supernatural properties. ${ }^{39}$ A special ministry of theatre and music was established to regulate the hierarchy of musicians employed for various functions. The court maintained a number of classical ensembles, principally the saing waing that accompanied raucous outdoor events, including theatre and puppet shows. Its musicians were particularly skilled in a repertoire of pieces matched to the setting and action of the drama. The number of registered court musicians

35 The Cambridge guide to Asian theatre, ed. James R. Brandon (Cambridge: Cambridge University Press, 2002), pp. 14-17. Lieberman, Strange parallels, pp. 190-91. Hla Pe, Burma: Literature, historiography, scholarship, language, life, and Buddhism (Singapore: Institute of Southeast Asian Studies, 1985), pp. 20-24.

36 Lieberman, Strange parallels, p. 194.

37 Jonathan Webster, 'Solitude and sandaya: The strange history of pianos in Burma', The Appendix 1, 3, July 2013, http://theappendix.net/issues/2013/7/solitude-and-sandaya-the-strange-history-of-pianosin-burma; Catherine Diamond, 'Burmese nights: The pagoda festival pwe in the age of Hollywood's “Titanic”, New Theatre Quarterly 16 (2000): 248n37. On opaya, see Diamond, 'Burmese nights': 239; and Catherine Diamond, 'A delicate balance: Negotiating isolation and globalization in the Burmese performing arts', TDR/The Drama Review 53, 1 (2009): 109n14.

38 Lieberman, Strange parallels, p. 188. The British census of 1901 found that 49 per cent of males across Burma as a whole were literate; the corresponding figure for females was 5.5 per cent (ibid., p. 189n286). Using different criteria, the 1891 census recorded a male literacy rate for those over fifteen of around 70 per cent and 3 per cent for females (Thant, The making of modern Burma, p. 241).

39 Singer, Burmese dance, pp. 16-17. 


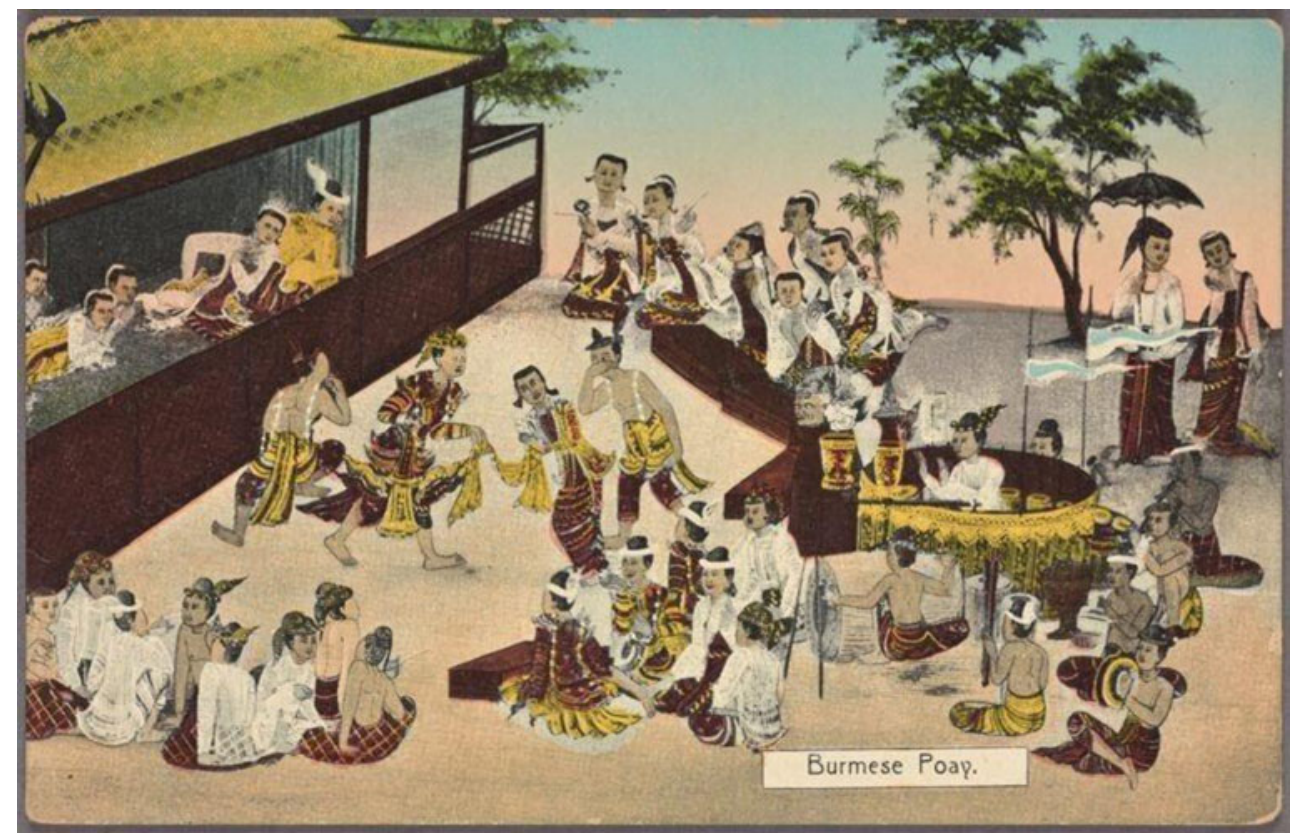

Figure 3. Burmese poay [pwe]; postcard, 1910

Art and Picture Collection, New York Public Library Digital Collections; http://digitalcollections.nypl.org/items/c2630359-a040-1508-e040-e00a180613de (last accessed 28 Aug. 2017).

reached into the hundreds in the mid-nineteenth century, ensuring the availability of highly accomplished performers. ${ }^{40}$

By the early 1880s, this vibrant scene had begun to register the impact of Western technology. The printing of cheap books accelerated the production and consumption of written dramas. In the 1870 s, dramatic scripts were published from the newly operating printing presses in Rangoon. By 1913, about 140 printed playbooks (pya-zat) were in circulation, according to the catalogues of the British Museum. ${ }^{41}$ Western stage design may have been introduced during the British occupation of Rangoon in 1852, when troops built a theatre on the upper terrace of the Shwedagon Pagoda. ${ }^{42}$ In 1872, a high Burmese official travelled to London and observed the production of a live play on stage, which may have led to innovations upon his return. ${ }^{43}$ In the early 1880 s, several proscenium stages, complete with trapdoors and moving

40 Ibid., pp. 16-21; Ward Keeler, Liner notes, Classical theatre music: Burma (Musique du théâtre classique: Birmanie), CD-1317/1318 (Geneva: Musée d'ethnographie, 2012); Gavin Douglas, Music in mainland Southeast Asia (New York: Oxford University Press, 2010), pp. 39-41; Hsin-chun Lu, 'The Burmese classical music tradition: An introduction', Fontes Artis Musicae 56, 3 (2009): 254-71.

41 L.D. Barnett, A catalogue of the Burmese books in the British Museum (London: British Museum, 1913), pp. 311-14.

42 Singer, Burmese dance, p. 26.

43 Michael W. Charney, Powerful learning: Buddhist literati and the throne in Burma's last dynasty, 1752-1885 (Ann Arbor: Center for South and Southeast Asian Studies, University of Michigan, 2006), p. 220 . 
scenery, were installed in the palace in Mandalay to complement traditional pavilions for dramatic presentation. These structures illustrate the penchant for novelty, as well as the large budget for entertainment, both of which grew astronomically under King Thibaw. ${ }^{44}$

\section{Balivala comes to Burma}

Given the royal passion for theatre, it comes as no surprise that performers from India were invited to Mandalay, as were the French and Italians. How did this encounter between Parsi theatre practitioners and a court addicted to pleasure unfold? What were the perceptions of the Burmese and of the Indians? Since the use of Burmese language sources is beyond the scope of this project, the Burmese reaction can only be teased from scant English records. Thibaw's courtiers no doubt were curious about the party travelling from Bombay, and the palace clearly thought the troupe worth inviting back, since they kept returning. But the response of the Burmese is missing from published accounts, unlike the situation elsewhere in Southeast Asia. ${ }^{45}$

Instead, evidence of Burmese interest comes from the archaeological record. King Thibaw built a theatre specially for the Parsi company, according to George W. Bird, a civil servant who lived for 20 years in Burma. In his detailed 1897 travelogue, he locates this playhouse on the south face of the Mandalay Palace:

The white portico over the carriage road on the south side was formerly the theatre built by King Thibaw for the 'Parsi Victoria Theatrical Company', who, by the king's command, proceeded to the capital in 1881 or 1882 , and were so well received and treated, that their stay extended over several months.

The stage has been removed, and the building is now utilized as a cab shelter during the heat of the day or in the rainy season.

The building adjacent to it was a sort of drawing room where the court assembled to witness the dramatic performances in the theatre close by .... This room is now used as the Officers' Mess of the European regiment forming part of the garrison. ${ }^{46}$

In 1885, the British completely overran and looted the palace and soon after turned it into Fort Dufferin. Some time before Bird's writing, the playhouse erected for the Parsis and the drawing room adjoining it had been converted to other purposes. Nonetheless, the fact of the playhouse's construction attests to the fond reception accorded the Indian thespians by the monarchy. ${ }^{47}$

44 Singer, Burmese dance, pp. 28-30.

45 Cohen reports that Parsi troupes toured peninsular Southeast Asia and the Malay world to great acclaim, citing an 1886 account from West Sumatra by a Dutch observer and Singapore newspapers following Parsi company tours in the 1880s and 1890s ('On the origin': 319-21). Parsi theatre companies began touring Indonesia in 1883 and were tremendously popular from their first appearance. Their tunes and plays were imitated in western Java, according to Bintang-Barat, a Batavia newspaper (cited in Cohen, Komedie Stamboel, p. 42).

46 George W. Bird, Wanderings in Burma (Bournemouth: F.J. Bright \& Son, 1897), pp. $265-6$.

47 Charles Duroiselle, superintendent of the Archaeological Survey of Burma, corroborates Bird in Guide to the Mandalay Palace (Rangoon: Government Printing, 1925). He does not mention Parsi theatre but identifies the Theatre Drawing Room (Pwe-Kyi-daw-zaung) as an 'apartment on the south, contained between the walls immediately above the street running along the Palace platform', and mentions that it was 'built in Thibaw's time' (p. 51). 
In contrast to the apparent diffidence of the Burmese, Indian sources attribute mythic status to K.M. Balivala and the Victoria Company's tours to Burma. Let us proceed to look at the Indian version of events, relying on theatre histories and newspaper reports of the time. Khurshedji Mehrvanji Balivala (1853-1913) was the principal actor and longtime manager of the Victoria Theatrical Company, the most renowned of all the Parsi troupes. The son of an actor, Balivala entered the profession while still in his teens and took over the company's management around 1878. He was known for his sweet singing voice as well as his talent for comedy; testimonials avowing his popularity fill the sources. ${ }^{48}$

Balivala's bold exploits were the stuff of legend. At the invitation of Sir Salar Jang, prime minister of the princely state of Hyderabad, Balivala led the Victoria Company on its first major journey in 1872. This success spurred him northward towards Delhi, Lucknow, and Calcutta in 1874. Next Balivala ventured over the Indian Ocean. Each trip presented challenges which, one by one, the charismatic Balivala successfully overcame, establishing his reputation for heroism and self-sacrifice in oral tradition. On the road to Hyderabad, Balivala carried just a shawl and blanket, such was his poverty. In Delhi, he danced on and on, despite nails protruding from the stage that pierced his feet. While travelling from Singapore to Penang, he fell from a rocking chair and almost drowned during a storm. ${ }^{49}$

In 1881, the Victoria Theatrical Company under Balivala travelled to Mandalay at the invitation of King Thibaw. This trip involved a large company of 27 members, 17 of whose names are on record. The run was long and well-compensated. The actors were welcomed with lavish gifts: fruits stuffed with gems, pits in the ground full of buried coins. In line with the king's reputation for extravagance, Balivala was hired to perform 35 dramas, for which he was paid Rs. 43,000. The company returned to Bombay with a hefty profit. ${ }^{50}$

Balivala and his performers returned to Mandalay in 1883, 1884, and $1885 . .^{51}$ These tours attracted much attention and were reported in often lurid terms. In 1881, Indian newspapers contrasted King Thibaw's misdeeds and neglect of governance with his attention to pastimes such as Parsi theatre shows. ${ }^{52}$ Similarly, narrating the infamous prison murders perpetrated by Thibaw's minions in September 1884, Major Edmond C. Browne reported:

Meantime the ruffian king and court have been holding high festival over the event to divert the people from thoughts of the true significance of the massacre, and make

48 'His sweet voice and musical renditions were very appealing .... In Bholi Jan he played Hijo Tarivala, and his singing caused throngs to gather in the Novelty Theatre.' Gupt, Parsi theatre, p. 157. For Balivala's achievements, the primary source is Dhanjibhai Patel, Parsi natak takhtani tavarikh [History of the Parsi theatre] (Bombay: Kaiser-i Hind Press, 1931), pp. 107-17.

49 Gupt, Parsi theatre, pp. 116-23, 158.

50 Ibid., pp. 121, 159.

51 The Times of India (Bombay), 29 Oct. 1883, p. 5; 17 Feb. 1885, p. 5; 9 Mar. 1885, p. 3. The Pioneer (Allahabad), 24 Feb. 1885, p. 4; For 1884, see Edmond C. Browne, 'Burma in 1885. Part II. Upper Burma', Calcutta Review (Jan. 1886), pp. 52-4.

52 From a column titled MANDALAY NEWS: 'The Rangoon Times says: ... Yet the King is not neglecting his pleasures and enjoyments. The Parsee Victoria Theatrical Company were setting up their theatre in the palace yard when the mail left, and expected to be able to give their first performance on Saturday last, the 17th September.' The Pioneer, 29 Sep. 1881, p. 5. 


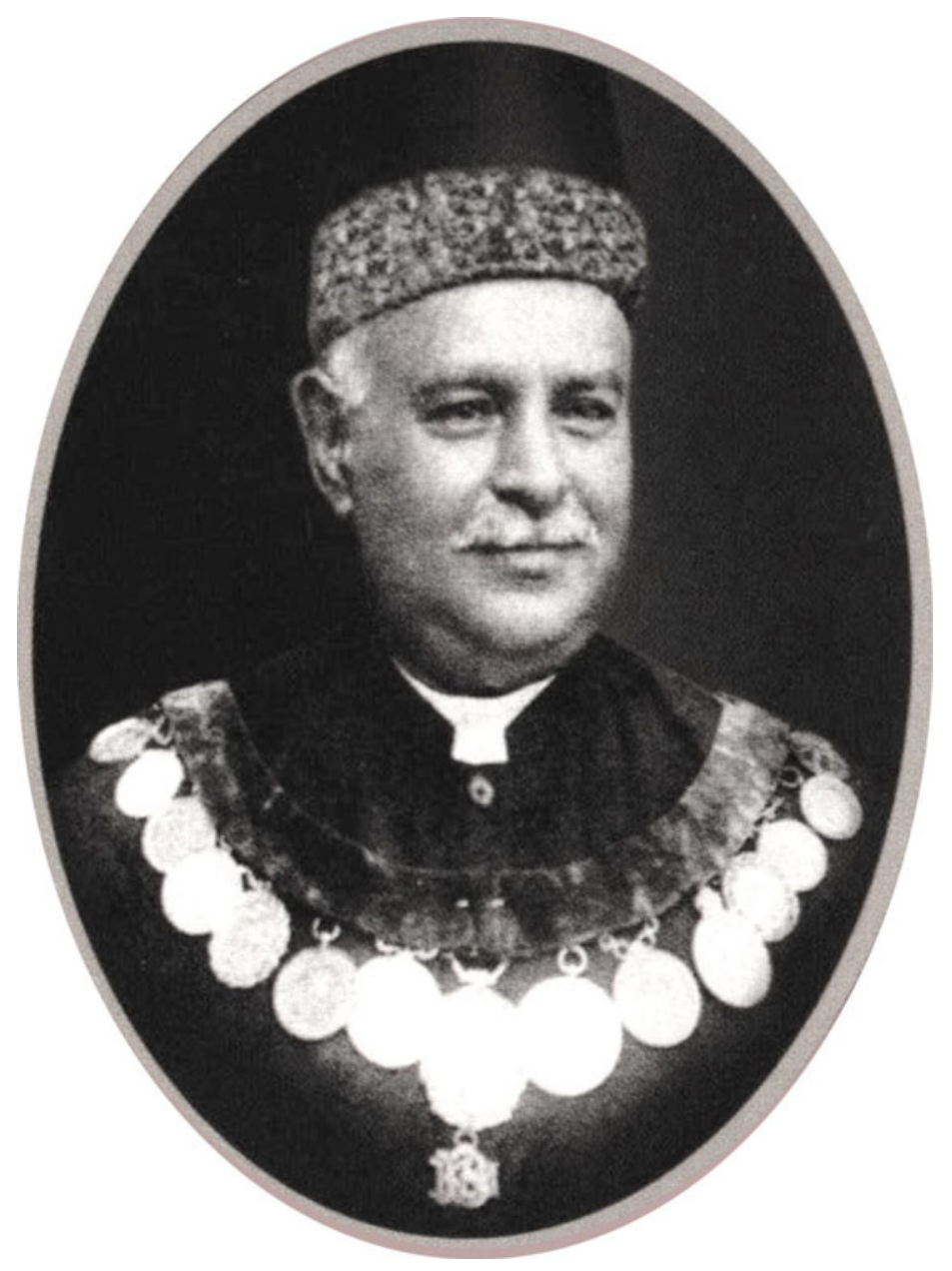

Figure 4. K.M. Balivala

Photograph courtesy of Meher Marfatia, Laughter in the house!: 20th-century Parsi theatre.

them regard it as the triumph of the nation over the nation's foes. Poays [pwes] are being held nightly and the Parsee Theatrical Company have just arrived, and in good time, to make sport in the palace. ${ }^{53}$

In the spring of 1885, on the threshold of the Third Anglo-Burmese War, three Parsi theatre actors were rumoured to have been murdered in Mandalay. The motive seems to have been romantic jealousy: 'some of the palace ladies looked upon them with favour'. ${ }^{54}$ The rumour was soon quashed, and the company reportedly left Burma intact. ${ }^{55}$ These sensational stories created the impression that Balivala's

53 Browne, 'Burma in 1885 ', p. 54.

54 Times of India, 17 Feb. 1885, p. 5.

55 The Pioneer, 24 Feb. 1885, p. 4; Times of India, 9 Mar. 1885, p. 3. 
tours were dangerous, and not without reason. Mandalay, unlike Rangoon, was outside of British control, and the palace had been the site of assassinations. Even after annexation, Upper Burma remained a zone of unrest as violent resistance to British occupation persisted.

At the time of Balivala's tours to Burma, reports in India emphasised the hazards, but in later accounts, the dominant theme was nostalgia for the Konbaung dynasty and royal largesse.

They [the Victoria Theatrical Company] performed several plays in Urdu and Hindustani before the now dethroned King and Queen, but they acted always on their knees before the royalty as was usual according to the custom of the country. Queen Sopaya Lat, who was said to have great influence with the ex-King, most lavishly distributed gold, pearls, emeralds, and rubies among the members of the company by way of rewarding their services. Both the ex-King and Queen were extremely kind and courteous to the proprietors and members of the company, and induced them to prolong their stay as long as they could in their territory. ${ }^{56}$

The bounty of the Mandalay court acquired even greater repute when contrasted with the dismal outcome of Balivala's subsequent trip to London. Invited to England after the final tour to Burma, Balivala suffered major losses.

The company after returning to Bombay went to England in 1886 to reap, as they thought, a rich harvest by giving theatrical performances in the different vernacular languages in some of the chief towns of the country. But here they were doomed to disappointment. They lost a goodly portion of their money on account of travelling and other heavy charges, and they returned to Bombay poorer in money though richer in histrionic experience. ${ }^{57}$

The two ventures were often linked: what Balivala earned in Burma, he 'squandered' in England. ${ }^{58}$

Each time the Victoria Company came to Burma, it passed through Rangoon. A few slight references suggest that Balivala performed in the capital city. Balivala is said to have retained a Rangoon resident named Kavas Gandhi as interpreter. The Victoria Company made a charitable contribution to the Dar-e Mehr Fund in Rangoon in 1884, possibly after a benefit performance. ${ }^{59}$ In addition, a special performance was arranged for Rangoon audiences in Gujarati by Balivala's nephew. ${ }^{60}$ This event may signal that other shows were held in Rangoon during the comings and goings of Balivala's troupe.

The Victoria Company under Balivala, in completing four successful tours to Burma, set a new standard for entrepreneurship and risk-taking. The prestige of attaining royal favour was as valuable as the financial return. One outcome of

56 Times of India, 1 Mar. 1888, p. 3.

57 Ibid.

58 Gupt, Parsi theatre, p. 159. See also 'The novelty theatre', Times of India, 5 Oct. 1891, p. 3; and The Sketch, 13 Mar. 1895, p. 352.

59 Gupt, Parsi theatre, pp. 121-2.

60 Somnath Gupta, Parsi thiyetar: udbhav aur vikas [Parsi theater: Origin and development] (Allahabad: Lokbharti Prakashan, 1981), p. 197. 
Balivala's exploits was to open up Burma as a site of Parsi theatrical adventurism. Although Mandalay lost much of its appeal as a performance venue after the fall of King Thibaw, Rangoon gained in importance. Artists in Bombay, hearing of Balivala's successes in Burma, were attracted to make the trip themselves. Balivala's interactions with Rangoon Parsis must also have generated interest in sponsoring the visits of Indian performers and sharing in the profits.

\section{Dosabhai Hathiram, a photographer's father}

Dosabhai Hathiram was one of the Bombay actors who made their way to Burma in Balivala's wake. For decades, Dosabhai based himself in Burma and worked the Indian Ocean circuit. Biographies of relatively unknown figures like Dosabhai have the capacity to anchor the particular to the general, to lend a valuable individual dimension to larger histories. ${ }^{61}$ In the next section, Hathiram's biography is assembled from disparate primary sources - historical newspapers, official documents, private records, published accounts of Parsi theatre. Stitching these fragments together, I try to imagine a life embedded within the connected worlds of commercial theatre, popular music, and imperial expansion in the Indian Ocean.

The story of this minor man of the theatre would have been lost entirely if not for the fact that Dosabhai had an illustrious daughter. Her name was Homai Vyarawalla, and she was a celebrated photojournalist in the India of the 1950s. Her photographs of world leaders such as Gandhi, Nehru, Mountbatten, and the Dalai Lama became iconic images and were published in Life and Time magazines. ${ }^{62}$ Importantly, she also documented the life of her father and contributed photographs, letters, and anecdotes about him to the retrospective of her work, lovingly assembled and written by Sabeena Gadihoke. ${ }^{63}$ Homai shared parts of the family archive with this author during an interview in 2001.64

Dosabhai Hathiram's life stretched across a long period of transformation in the subcontinent's cultural history. He was born in 1859, six years after the very first Parsi dramatic troupe performed in Bombay. By the time he turned ten, some twenty amateur drama clubs were active, and the Parsi theatre was on the road to major expansion. He made his stage debut in Bombay in the 1880s, just as melodrama and social realism were catching fire and the popularity of Parsi theatre was spreading among spectators of all classes. At his death in 1931, the talkies had begun to edge out live stage shows, and the final days of Parsi theatre had arrived.

Little is known of Dosabhai's antecedents. His daughter Homai remembers that both her parents had priestly ancestors in Gujarat, but neither had much schooling. ${ }^{65}$ This was not an uncommon circumstance for Parsis of limited means. Dosabhai may have been exposed to Parsi theatre as a boy and recruited by a relative. According to

61 Clare Anderson, Subaltern lives: Biographies of colonialism in the Indian Ocean world (Cambridge: Cambridge University Press, 2012), p. 12.

62 Haresh Pandya, 'Homai Vyarawalla, pioneering Indian photojournalist, dies at 98', New York Times, 28 Jan. 2012.

63 Sabeena Gadihoke, India in focus: Camera chronicles of Homai Vyarawalla (Delhi: Parzor Foundation; Ahmedabad: Mapin, 2006).

64 I met Homai Vyarawalla at her home in Baroda on 3 Jan. 2001, where she graciously served me homemade cake and tea and recounted details of her father's history.

65 Gadihoke, India in focus, p. 11. 
Somnath Gupt, several men with the surname Hathiram were active on the stage when he was a young man. ${ }^{66}$ His elder brother, Mehrvanji Agha, was a sometime comedian. ${ }^{67}$ Performing in plays also appealed to Dosabhai's two sons, Homi and Siavak, who were amateurs in the Gujarati theatre. ${ }^{68}$

Dosabhai's career began as a 'lady actor', the quaint Indian-English term used for a cross-dressed performer of female roles (in the vernacular, stri bhumika or stri part). ${ }^{69}$ For information on the early part of his career, Dhanjibhai Patel's theatre history, written in Gujarati, is invaluable. ${ }^{70}$ Dosabhai's first success was as Bachu, the unfortunate heroine in the melodrama, Dukhi Gul (The Unhappy Gul). This play was a version of a bestselling Victorian novel, East Lynne by Ellen Wood (1861). Dukhi Gul was written by Edalji Mistri, known as 'Kolejar' (collegian). Mistri based his script on an earlier adaptation, the novel Dukhiyari Bachu by social reformer Kaikhushro N. Kabra. ${ }^{71}$ The play was one of the first 'socials', a distinct genre centred on women, the family, and the tensions of modernity, to be performed on the Parsi stage. ${ }^{72}$

The historical South Asian newspaper archives disclose the circumstances of Dukhi Guls performance. It was put on by the Parsi Natak Mandali (Parsi Dramatic Company) in a successful run at the fashionable Gaiety Theatre in 1883. Not coincidentally, the Gujarati play alternated on the boards with East Lynne in English, starring Louise Pomeroy, a well-known Australian actress. ${ }^{73}$

Dosabhai's performance in Dukhi Gul is significant for several reasons. First, it marks his stage debut. Second, the play is an early example of an Indian-language

66 Rustamji H. Hathiram was a founding partner of the Parsi Theatrical Company, the very first such company (Gupt, Parsi theatre, p. 139). Two gentlemen named Khurshedji Behram Hathiram and Hormasji Behramji Hathiram acted in female roles in the early 1870s (ibid., pp. 108, 137).

67 Patel, Parsi natak, p. 387.

68 Gadihoke, India in focus, p. 15.

69 The practice of men playing women's parts has a long history in Indian theatre. It underwent a period of resurgence in the late 19th century. Male apprentices in the Parsi theatre routinely started out as chorus 'girls' and went on to heroine roles. Impersonators remained popular even as actresses ventured onto the stage. Cross-dressed male actors introduced fashions and deportment that set the standard for respectable appearance, enabling previously secluded women to enter public spaces and maintain their reputations. See Kathryn Hansen, 'Making women visible: Gender and race cross-dressing in the Parsi theatre', Theatre Journal 51, 2 (1999): 127-47.

70 Dosabhai Hathiram's career is described in Patel, Parsi natak, pp. 384-7. Patel's sketches were first published in the newspaper Kaiser-i hind. His account is the basis for later surveys, including Abdul Alim Nami, Urdu thetar [Urdu theatre], vols. 1-4 (Karachi: Anjuman-i Taraqqi-i Urdu Pakistan, 1962-75), and Somnath Gupta, Parsi thiyetar.

71 Dukhiyari Bachu was first published in Stribodh, Kabra's pioneering magazine for women. G.C.M. Birdwood, The Stree Bodhe and social progress in India: A jubilee memorial (Bombay: Stree Bodhe Office, 1908), p. 79. Later, it was published independently in five parts (1885-86). J.F. Blumhardt, Catalogue of Marathi and Gujarati printed books in the library of the British Museum (London: British Museum, 1892), pt. II, p. 57.

72 Patel, Parsi natak, pp. 381-4. The Indian 'social' or 'social play' (samsari khel or samajik natak) derived from Victorian domestic melodrama. It joined older genres such as the mythological, the romance, and the historical, eventually overtaking them in popularity. See Hansen, 'Mapping melodrama': 23-6.

73 Miss Pomeroy's season in Bombay began on 14 Mar. 1883 and ended around 20 April 1883. Times of India, 14 Mar. 1883, p. 4; 6 Apr. 1883, p. 2 (review); 19 Apr. 1883, pp. 2, 3. Dukhi Gul ran between 14 Mar. and 15 Apr. 1883. Times of India, 14 Mar. 1883, pp. 4, 5; Kaiser-i hind, 18 Mar. 1883, p. 207; Kaiser-i hind, 15 Apr. 1883, p. 279. 
play adapted from an English melodrama. ${ }^{74}$ Third, the event establishes Dosabhai's residence in Bombay in 1883. This helps to pinpoint the date of Dosabhai's departure for Burma.

\section{The Parsi-Jewish connection}

Dosabhai's life took off in an unexpected direction when his path intersected with that of Miss Jamila, also known as Jamila Begum. This rather sensational part of the biography comes from the records of Dhanjibhai Patel, not from the family history kept by Homai Vyarawalla. It lacks substantiation from independent sources such as historical newspapers, and is perhaps best read as suggestive of broad themes rather than reliable in all details. ${ }^{75}$

In his earlier days, Patel's narrative goes, Dosabhai Hathiram was very well-built and good-looking. A Baghdadi Jewish actress named Jamila Begum took a shine to him. She had established her own theatre company in Bombay, but was not very familiar with the business side of things. Paying Dosabhai Hathiram a handsome advance, she hired him as the director of her company. Next, she abruptly took the entire company, including Dosabhai as manager and director, and departed for Rangoon. ${ }^{76}$

Jamila belonged to the earliest generation of actresses in the Parsi theatre. According to Patel, she attained renown as the Sabz Pari in the Indar sabha and worked in the Ladies and Gentlemen Theatrical Club owned by Navroji Golvala. These associations place her in Bombay in the early to middle 1870s, a decade or so before Dosabhai's debut in Dukhi Gul. Her departure for Burma with Dosabhai would have had to occur after his Bombay performance, in 1884 or later.

Jamila Begum's story is shrouded in mystery, but the consensus is that she was Jewish (yahudi). As such, she stands at the head of a long line of actresses considered foreign or 'other' who populated the Parsi theatre and early Indian cinema. In the 1870s, social taboos and stereotypes of actresses as prostitutes made it almost impossible for respectable Indian women to perform on stage. The gap was filled by outsiders, generally Anglo-Indian, Jewish, and European women. In addition to their greater freedom from patriarchal norms, these women were considered desirable on account of their fair skin colour and modern ways. ${ }^{77}$ Jewish actresses like Patience Cooper, Ruby Myers (Sulochana), and Esther Abraham (Pramila) all got their start in travelling theatre companies before emerging as stars in Indian films. Several Jewish actors and directors were prominent in the early years of motion pictures: Elizar, Joseph David, Daniel David, and Ezra Mir. ${ }^{78}$

74 For an account of the transmission and transmutation of stage melodrama as it moved from England to Australia and thence to India, see Hansen, 'Mapping melodrama'.

75 Approximately eleven months of one historical newspaper, The Rangoon Times, available on microfilm from the British Library, were browsed in search of corroborating evidence. The dates covered were January-April 1887 and January-May 1888. Some items related to Burmese theatre and European entertainments were found, but nothing turned up on Parsi theatre or Dosabhai Hathiram.

76 Patel, Parsi natak, pp. 384-6, is the primary source. Reiterations appear in Gupt, Parsi theatre, p. 171, and Nami, Urdu thetar, vol. 4, pp. 326-7.

77 Hansen, 'Making women visible': 144-7.

78 Navras Jaat Aafreedi, 'The Jews of Bollywood: How Jews established the world's largest film industry', Asian Jewish Life 17 (Winter 2016); http://asianjewishlife.org/pages/articles/AJL_Issue17_ Winter2016/AJL_Issue17_The-Jews-of-Bollywood.html (last accessed 28 Aug. 2017). 
Most of these leading lights belonged to the Baghdadi Jewish community. 'Baghdadis' included Arabic-speaking Jews from Iraq, Syria, the Ottoman empire, Yemen, Persia, and Afghanistan. Pursuing opportunities for trade, Baghdadi Jews began coming to India in the eighteenth century, settling in Bombay, Poona, and Calcutta. They travelled to Rangoon, Penang, and other cities to the east as well. Baghdadi Jews built a parallel network to that of the Parsis throughout the Indian Ocean region. In India, they learned the lingua franca, Hindustani, although the upper classes resisted assimilation to Indian customs as they shifted from a Middle Eastern to an anglophilic cultural identity. ${ }^{79}$ Like the Parsis, the community was known as a 'model minority' and was considered loyal to the British. In reality, alongside the more prosperous members, the middle class was sizeable, and a large number of poor and working-class Baghdadi Jews eked out a meagre existence. ${ }^{80}$

Baghdadi Jewish women were active in both the public and private domains. ${ }^{81}$ Women as well as men travelled along the trade circuits, setting up households in 'Jewish Asia' and bearing children en route. They worked as householders, merchants, and entrepreneurs. Some were employed as actresses and singers. Jewish performers like Jamila were working women who took advantage of the employment opportunities emerging in cosmopolitan entertainment districts across the globe. Jamila and other women were able to travel between Iraq, India, and Burma because of the networks that members of their community had already established.

Jamila built a theatrical circuit through her own effort, taking junior artistes from Baghdad to Bombay with her and attracting Parsi partners once there. She and Dosabhai formed a managerial team, one of numerous male-female partnerships in which artistic and romantic impulses merged and reinforced each other. In the Parsi theatre world, such alliances usually featured a junior actress paired with a senior male actor-director, e.g. Mary Fenton and K.P. Khatau, Munnibai and K.M. Balivala. Dosabhai and Jamila were more evenly matched in age, and she was more experienced and well-travelled than he was. Her role was that of company owner, and Dosabhai was subordinate, working for her as director on contract. The gender inversion may have contributed to tensions in the relationship, as might religious and ethnic differences. But perhaps the same factors produced artistic dynamism and facilitated creativity. The Parsi-Jewish connection reaped rewards elsewhere in India's entertainment economy. In the case of Alam Ara, the first talkie of India, the film was directed by a Parsi, Ardeshir Irani, and written by a Bene Israel Jew, Joseph David, who had long been associated with the Parsi theatre.

The length of Dosabhai and Jamila's collaboration is difficult to determine. The couple may have married or presented themselves as married, insofar as Homai Vyarawalla's mother was said to be Dosabhai's second wife. ${ }^{82}$ Interracial unions

79 Until 1885, the British classified Baghdadi Jews as 'European', and as late as 1929 the community fought for status as a 'white race'. Joan Roland, The Jewish communities of India: Identity in a colonial era, 2nd ed. (New Brunswick, NJ: Transaction, 1998), pp. 15-20, 56-7. See also Ruth Fredman Cernea, Almost Englishmen: Baghdadi Jews in British Burma (Lanham, MD: Lexington, 2007), pp. 71-8.

80 Jael Silliman estimates that in Calcutta in the nineteenth century, 15 per cent of Baghdadi Jews were wealthy, 35 per cent were middle class, and fully half were poor and dependent upon Jewish charities. Jael Silliman, Jewish portraits, Indian frames (Calcutta: Seagull, 2001), p. 28.

81 Silliman, Jewish portraits, pp. 29-49.

82 Gadihoke, India in focus, p. 10. 
were not unusual among the Parsis in Burma, with Parsi men taking Burmese wives or mistresses. ${ }^{83}$ By moving to Burma, the mixed-race couple may have found greater acceptance for their relationship as well as a more advantageous climate for their chosen profession of theatre.

In a sudden twist, however, the relationship went sour. Dosabhai was accused of murdering Jamila in Rangoon. Here is Patel's telling:

One evening, I got the news that Dosabhai Hathiram had been sentenced to hang by the High Court in Rangoon. The Parsis of Rangoon were trying to reduce the sentence, and they had appealed to the Honourable Viceroy. I happened to see a copy of their petition. The petition with signatures was sent to the Viceroy, and as a result Hathiram's death sentence was commuted to exile for life.

It was said that Dosabhai Hathiram had murdered the Jewish woman with whom he went to Rangoon as manager and director. For a number of years, he endured the punishment of exile and was almost erased from the memories of his dear ones. Theatre people totally forgot about his existence. But after a period of some years, he was pardoned for good behaviour on an official occasion, and he came back and settled in Bombay. ${ }^{84}$

This scandalous turn of events marked the start of a long period abroad for Dosabhai, and one that altered from voluntary residence to exile imposed under colonial law. Dosabhai was apprehended for murdering Jamila, then was convicted and given the maximum sentence. The matter did not stop there. The young actor had many loyal fans and admirers in the Parsi community, and they rallied to his rescue. When they circulated a petition to the Viceroy of India pleading for clemency, he was saved from death by hanging. His sentence was commuted to lifelong exile.

Antagonisms and jealousies could easily have developed between the two co-stars. Actresses tend to attract admirers, and Dosabhai could have succumbed to his suspicions. The couple may have fought over money or property, or parted ways professionally, splitting the company and joining other drama partners. Whatever the motives that led to the assault, Jamila's murder surely attracted wide notice. Her fans in Rangoon may have contributed to the public outcry leading to Dosabhai's arrest and prosecution. His standing among Parsis as an actor and bearer of Indian cultural traditions similarly brought the Parsi community together to petition for a reduction of his sentence.

Patel's narrative converts the scandal to a celebration of Hathiram's reputation, through emphasis on the public campaign mounted on his behalf. Although the Parsis' petition to the Viceroy has not been found, it attests to the devotion of Hathiram's audience and his fame as an artist. Yet the murder in Burma undoubtedly besmirched his public image. He was arrested, tried, and convicted of a capital crime.

83 Intermarriage between Parsi men and Burmese women seems to have been more common in the nineteenth century than the twentieth, when there were many fewer Parsi women than Parsi men in Burma. At that time, offspring of such couples were considered fully Parsi. Sharafi, Law and identity, p. 295.

84 Patel, Parsi natak, pp. 386-7; many thanks to Sushma Merh-Ashraf and Aarti Bhalodia for help with the translation. 
He must have served time in prison. The gaps in Patel's account suggest the ignominy that accrued from this horrific deed. ${ }^{85}$

\section{The persistence of Parsi theatre}

Dates are difficult to pin down, but after some years, perhaps a decade or more, Dosabhai was pardoned and allowed to return to India. This probably happened early in the twentieth century. After returning home, he married Soonamai, a woman twenty years his junior. She was a widow, and he had a criminal record, making them 'suitable' as marriage partners who each bore a stigma of some sort. The marriage must have occurred in 1910 or earlier, since their daughter Homai was born in 1913, and two brothers preceded her in the birth order.

In April 1919, authorities in Singapore, then a Crown colony of the British empire, issued a passport from the Straits Settlements to one Dosabhoy Nawroji. The document listed his birthplace as Bombay and his profession as 'Actor's Director'. With him were travelling his wife, aged 32, and a daughter, aged 6, both unnamed. This passport's owner was Dosabhai Hathiram, and the other two travellers Soonamai and Homai. Homai preserved the passport as a keepsake and presented photographs of its pages to this author.

Homai recalls a childhood spent travelling with her father's troupe in Southeast Asia. The passport places Dosabhai and his kin in Singapore in 1919, making it plausible that the threesome visited Penang, Colombo, and other cities between 1916 and that date. In a final voyage together, the Hathirams travelled on the passport and reached Bombay. This marked the end of a phase of nomadic existence for Homai and her mother. Homai assumed the life of an urban schoolgirl and later studied at St. Xaviers' College and J.J. School of Art, both prestigious institutions. ${ }^{86} \mathrm{Her}$ mother set up a household in Tardeo, a Parsi neighbourhood.

Her father, however, left soon afterward, returning to Burma. He was appointed director of a Rangoon theatre company owned by Mam Shah, and there he staged a number of popular productions. He continued to reside in Burma, working in the theatre line, until overcome by indigence and ill health. Near the end of his life, he returned to Bombay, where he died in 1931.

Dosabhai's movements around this time intersected with those of other Parsi theatre veterans. Balivala's Victoria Theatrical Company travelled to Surabaya, Java, in $1898 ;^{87}$ the Parsi Theatrical Company owned by the Apu brothers went to Colombo in $1898 ;^{88}$ the Parsi Alfred Company of K.P. Khatau to the same city in $1908 ;^{89}$ the New Alfred Theatrical Company to Singapore in $1910 ;{ }^{90}$ and so on. Whereas all of these journeys were transacted by major companies, lesser companies too ventured to foreign ports.

85 It is improbable that Homai Vyarawalla knew anything of this earlier phase of her father's life. Out of respect for her memory of her father, I delayed writing this article until after her death.

86 Gadihoke, India in focus, pp. 17-20.

87 Cohen, Komedie Stamboel, p. 280.

88 Gupt, Parsi theatre, p. 142.

89 D.V. Hapuaracci, Sinhala natya itihasaya, 1860-1911 [History of Sinhala drama] (Colombo: Lake House, 1981), pp. 405-8. I am grateful to Francesca Bremner for Sinhala translation assistance.

90 Vladimir Braginsky and Anna Suvorova, 'A new wave of Indian inspiration: Translations from Urdu in Malay traditional literature and theatre', Indonesia and the Malay World 36, 104 (2008): 146. 


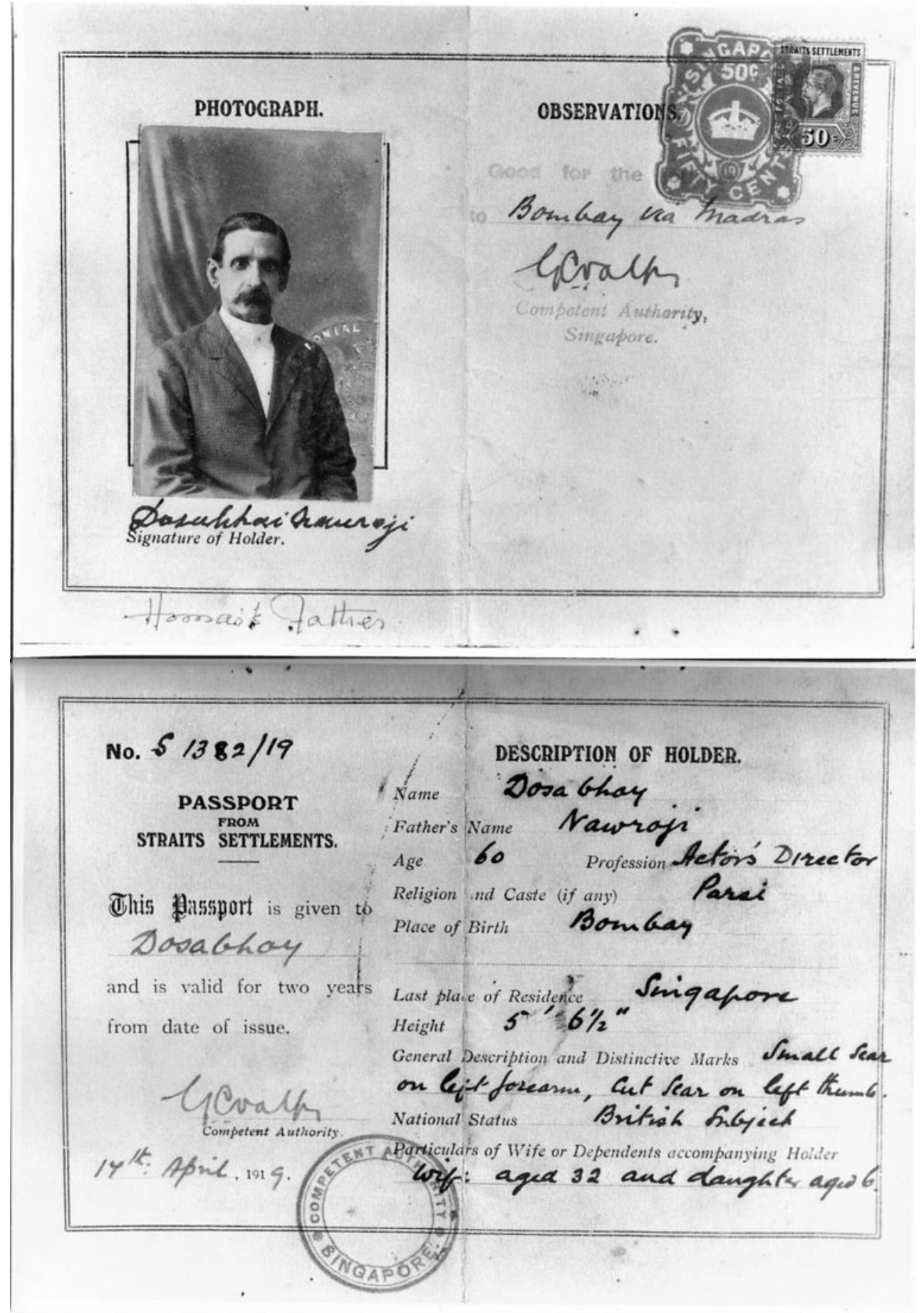

Figures 5 \& 6. Dosabhai Hathiram's passport

Photographs courtesy of the late Homai Vyarawalla. Author's collection. 
In India, Parsi theatre continued to hold sway. The number of companies operating from cities large and small exploded. For the period 1901 to 1965, Abdul Alim Nami enumerates some 220 Parsi-Urdu theatre companies, marking the extraordinary circulation of Parsi theatre in the twentieth century. ${ }^{91}$ Burma being counted as part of India, Nami includes Rangoon in his list. Five of Nami's itemised companies were based in Rangoon. These were the Empire Theatrical Company of Burma, active in 1911 to 1912; Mam Shah Bee Theatres, founded in 1919; the Great Eastern Parsi Theatrical Company, active 1927 to 1933; the United Theatre Company of Rangoon, founded in 1932; and the Nizam Theatrical Company of Rangoon, dating to $1936 .{ }^{92}$

Both the Empire Company and Bee Theatres were owned by one Mam Shah, a Memon from Bombay. Described by Nami as a clever businessman, Mam Shah got involved with commercial theatre in Rangoon around 1910. By 1912, his Empire Company was travelling to Penang and cities to the east, even to the Philippines and China. The Indar sabha was among the perennial Urdu favourites this company staged. Two works of the popular playwright Agha Hashr Kashmiri, Bilva mangal and Yahudi ki larki, were also regular items in the repertoire. They were performed in Singapore by Hashr's brother, Agha Mahmood. ${ }^{93}$

The names of the companies that Dosabhai Hathiram directed in Rangoon are not known, and from 1900 until 1919, details of his theatrical activities are absent. However, Nami distinctly mentions him as the director of Mam Shah's second company, Bee Theatres, in 1919. For this enterprise, Nami says Mam Shah went to Delhi to recruit actors and came back with 33 artists, including Dosabhai. The company included several actresses of Indian origin (including Begum Mam Shah, presumably Mam Shah's wife, said to be a Bengali) and a number of young Burmese women. Among the plays Hathiram directed was Saubhagya Sundari, a Gujarati hit. Hathiram was successful at turning what had been an amateur drama club into a professional company, and his productions were well received in Rangoon. ${ }^{94}$

Nami's brief sketches appear to be based on handbills and newspaper clippings. The sources are not cited, and verification is difficult. Speculating beyond Nami, Mam Shah could have been an important figure in Dosabhai's life. As a fellow Gujarati and theatre sponsor, he probably knew Dosabhai from Rangoon prior to 1919, and possibly also from circles in Bombay. Dosabhai was perhaps a member of Mam Shah's first company, the Empire, and if so, he may have gone to Penang and East Asia in 1912 with the troupe.

In the event, Dosabhai's contract with this employer ended in the 1920s. During his final years in Rangoon, Dosabhai sought assistance from Jehangir Khatau, according to his letters to his daughter Homai. Jehangir was the son of K.P. Khatau, a famous actor and the director of the eminent Parsi Alfred Theatrical Company. The Alfred Company had toured the Indian Ocean in 1908 and possibly 1913. Jehangir inherited the company's reins after his father's death in 1916. He may have helped lead the earlier eastern tours; possibly he had intentions to mount another. Dosabhai's correspondence suggests that Jehangir was producing theatre shows in

91 Nami, Urdu thetar, vol. 4, pp. 8-16.

92 Ibid., pp. 233-4, 305-7, 311-13, 318, 325.

93 Ibid., pp. 233-4.

94 Ibid., pp. 311-13. 
Burma, either on his own or through the old Alfred organisation. Whatever the case, Dosabhai's expectations of him proved to be in vain. As Dosabhai wrote to his daughter in 1931, the year he died:

\begin{abstract}
More than half the number of people here (in the company) are stranded for lack of money ... The manager doesn't seem to stay in Rangoon ... How can I ask him for money when he is in trouble as well ... Tell your mother that I wrote to Jehangir Khatau (the owner of the company) about ten days back and he has not even cared to reply. So I can't have any faith in him ... Don't worry about me. I am hoping that something may crop up by the end of the month ... I live in the hope that Khatau will make arrangements for me to reach Bombay. ${ }^{95}$
\end{abstract}

This missive suggests that Khatau, company owner and benefactor, and Hathiram, director, actor, and dependant, had a relationship of a certain standing. Although Jehangir Khatau is not mentioned by Nami or other sources in connection with Burma, it appears that he too had sought opportunity in this fabled land of plenty for theatre folk.

\title{
The cosmopolitan context
}

To summarise, the Parsi theatre was a going concern in the entertainment scene in Burma for 55 years, if not longer. It began with the brilliant tours of Balivala's Victoria Company to the court of Mandalay from 1881 to 1885 . The king ordered a new Western-style stage to be constructed in the palace for the players and lavished hospitality upon them. After the fall of Mandalay to the British, Rangoon assumed a larger role in cultural production. Dosabhai Hathiram and Jamila Begum were two entertainers from Bombay who sought fortune there, probably as early as 1886 . Dosabhai fell afoul of the law and vanished for a time, but Parsi theatre continued to thrive.

At the turn of the century, the central zone of the capital city became progressively more Indian in its population and lifestyle, and entertainments of all kinds flourished. Burma continued to attract touring Parsi troupes from the subcontinent, and new Parsi theatre companies were formed in Rangoon itself. With the Burmese port as point of origin, companies like the Empire of Mam Shah explored opportunities to the east along the Indian Ocean rim. Dosabhai resurfaced in Singapore as a married man with a child in 1919. He returned to India briefly and then spent his final decade in Rangoon. The last recorded Parsi company of Burma was the Nizam Theatrical Company, founded in 1936.

As Burma became an essential node in its network, the Parsi theatre contributed to the cosmopolitan ambience of colonial Rangoon. Comedies, melodramas, and farces, delivered in Urdu, Hindustani, or Gujarati, were accompanied by songs in even more tongues. The stage was a showcase for acting talent and for the beguiling charms of female performers of different backgrounds. Jamila Begum set the fashion, capitalising on her exotic appeal as a Baghdadi Jew. Burmese dancers and actresses joined Mam Shah's companies and likely others. The composition of troupes, managers, and audiences evolved towards greater diversity as mixed race communities,

95 Letter from Dosabhai Hathiram to Homai Vyarawalla, dated June 1931. Gadihoke, India in focus, pp. 16-17. 
Indo-Burmese and Eurasian, developed. ${ }^{96}$ These trends may have led to linguistic and musical hybridisation - skits and songs in Burmese, for example, or plot material picked up from local tales and contemporary affairs. The ability of the Parsi theatre to absorb and adapt was legion, but the tangible evidence in the case of Burma is slim.

Over the same duration, the infrastructure for European entertainments was built up, and performance venues proliferated. In 1887-88, the Rangoon Times ran advertisements for shows by Christy's Minstrels, Webb's Marionettes, Crofton and Ferrell's Dramatic Company, The Cheshire Regiment Dramatic Society, and Signor Chiarini's Circus. ${ }^{97}$ The newspaper made no mention of 'native entertainments', a category often included in the Indian press. Most anglophone performances were held in the Assembly Rooms, a 'huge, barn-like structure' built in $1854 .{ }^{98}$ In 1898 the decrepit Assembly Rooms were replaced by the new Jubilee Hall, 'one of the best appointed theatres in the Orient'. ${ }^{99}$ The Strand Hotel, the Royal Hotel, and Minto Mansions added to the available facilities, serving as contact zones where ethnic and national groups could intermingle. British, American, Canadian and Australian entertainers poured into Burma; a stay of two weeks guaranteed a handsome profit. ${ }^{100}$

Much less is known about the location of Parsi theatre activity in Rangoon. High-end colonial buildings were surely beyond the means of Indian troupes and not well-suited, given their clientele. Parsi theatre may have shared the stages utilised by zat pwe companies, such as the 'large iron shed' with a platform at one end rented by Po Sein in 1899. ${ }^{101}$ Might such facilities have given cause for naming one of Rangoon's streets 'Theatre Road'? This street is clearly delineated on a 1914 map, to the north of Jubilee Hall and south of the Shwedagon Pagoda in the Cantonment. ${ }^{102}$ Theatre Road was once home to the exiled Mughal king, Bahadur Shah Zafar. Today it is called Zi Wa Ka Street and is the site of Zafar's tomb. No explanation for its former name has been found.

As for the sphere of Burmese theatre, the rupture of 1885 compelled court musicians and performers to seek alternative employment. The career of the famous dancer, Ma Htway Lay (1867-1927), illustrates one individual's successful passage from a sinecure in the palace to a high-profile professional life in the public eye. ${ }^{103}$ Over the next several decades, zat pwe transformed from a courtly artefact with a limited audience to a mass entertainment with unquestioned commercial appeal. Companies grew increasingly prosperous and well organised. Cities, towns, and countryside were linked in a vibrant entertainment network with a star system, spectacular performance styles, and new music and

96 In Java, people of mixed Indian and Indonesian parenthood sustained Parsi theatre and contributed to the growth of Komedie Stamboel. The Jawi Peranakan played the same role in the Straits Settlements with regard to Bangsawan. Cohen, Komedie Stamboel, p. 281; van der Putten, 'Bangsawan': 270; Braginsky and Suvorova, 'New wave': 135.

97 Rangoon Times, 22 Mar. 1887; 1 Feb. 1888; 3, 8, 19, 23 Apr. 1888.

98 B.R. Pearn, A history of Rangoon (Rangoon: American Baptist Mission Press, 1939/1971), p. 203.

99 Selth, Burma, Kipling, p. 177.

100 Ibid., p. 179.

101 Kenneth (Maung Khe) Sein and J.A. Withey, The great Po Sein: A chronicle of the Burmese theater (Bloomington: Indiana University Press, 1965), p. 37.

102 Map of Rangoon, Burma, from Indien: Handbuch für Reisende (Leipzig: Verlag von Karl Baedeker, 1914). Perry-Castañeda Library Map Collection, University of Texas at Austin. http://www.lib.utexas. edu/maps/historical/baedeker_indien_1914/txu-pclmaps-rangoon_1914.jpg.

103 Noel F. Singer, 'The last diva of Mandalay', Arts of Asia 37, 3 (2007): 78-93. 
dance items. Actresses like Htway Lay were photographed by Felice Beato and others, their images circulated on postcards and cartes de visite. Even though large numbers of performers migrated to Rangoon, Mandalay retained its stature as the cultural heartland. By the early 1900s, over 100 theatrical troupes operated from Mandalay. ${ }^{104}$

A host of innovations in zat pwe ensued during the post-Konbaung period. Some are attributed to the figure who dominated the popular theatre in the early twentieth century, the renowned actor-manager Po Sein (1880-1952), but may have longer histories. The practice of charging admission, for example, supposedly began with Po Sein. ${ }^{105}$ Companies rented space in enclosed arenas and performed on a raised stage with artificial lighting. Sponsors and performers were bound by contracts, the breach of which could result in lawsuits. ${ }^{106}$ The repertoire incorporated new themes, and an immense number of printed dramatic compositions were sold in the market. Dance items reflected new norms of propriety; Po Sein is said to have begun the practice of male and female physically touching (ever so slightly) during their duet. Increasing emphasis on eroticism was visible too in the rage for transgender actors such as Aung Bala, Po Sein's partner for a time. Choruses of dancing girls were added, and all-female companies sprang up, led by the principal actress. ${ }^{107}$

Zat pwe was thus far from static. Its dynamic response to the upheaval of British occupation, while inevitably decried as decadent by some, ensured that Burmese theatre remained competitive in the cosmopolitan entertainment economy. Parsi theatre and Burmese popular theatre at this time evolved in tandem: both were increasing troupe size, incorporating chorus lines, ramping up spectacle. The progression suggests the likelihood of sharing and imitation across linguistic lines. Po Sein was somewhat acquainted with Parsi theatre, through shows he witnessed in Burma. He also was no stranger to British theatrical performances. In 1913, he travelled to India under the auspices of His Master's Voice, the recording company, and visited Allahabad and Calcutta. ${ }^{108}$ Although the extent of his contacts with Indian theatrical personnel and exposure to live performances is unclear, it can be assumed that he observed and adopted whatever he found to be suited to his own artistic and entrepreneurial interests.

\section{The last act}

If, at this relatively late date, Parsi theatre and zat pwe converged, developing similar strategies to ensure audience support, Parsi theatre nonetheless left scarcely a dent behind. No derivative dramatic form emerged, no intermediary genre such as Nurthi or Bangsawan arose. Parsi theatre made no imprint on the urban landscape; no buildings like the Gaiety Theatre in Bombay were erected. Nor did the legendary popularity of Parsi theatre songs have a discernible effect. Characteristic Indian instruments such as the harmonium and tabla did not join the Burmese orchestra, and the system of ragas and talas remained an alien import.

104 Singer, 'The last diva', 86.

105 Singer, Burmese dance, p. 54.

106 A case before the Rangoon Sessions Court concerned a contract by a troupe of Burmese actors for

30 performances, only 16 of which were completed. Rangoon Times, 22 Mar. 1887.

107 Singer, Burmese dance, pp. 59-65.

108 Sein and Withey, The great Po Sein, pp. 57, 79. 


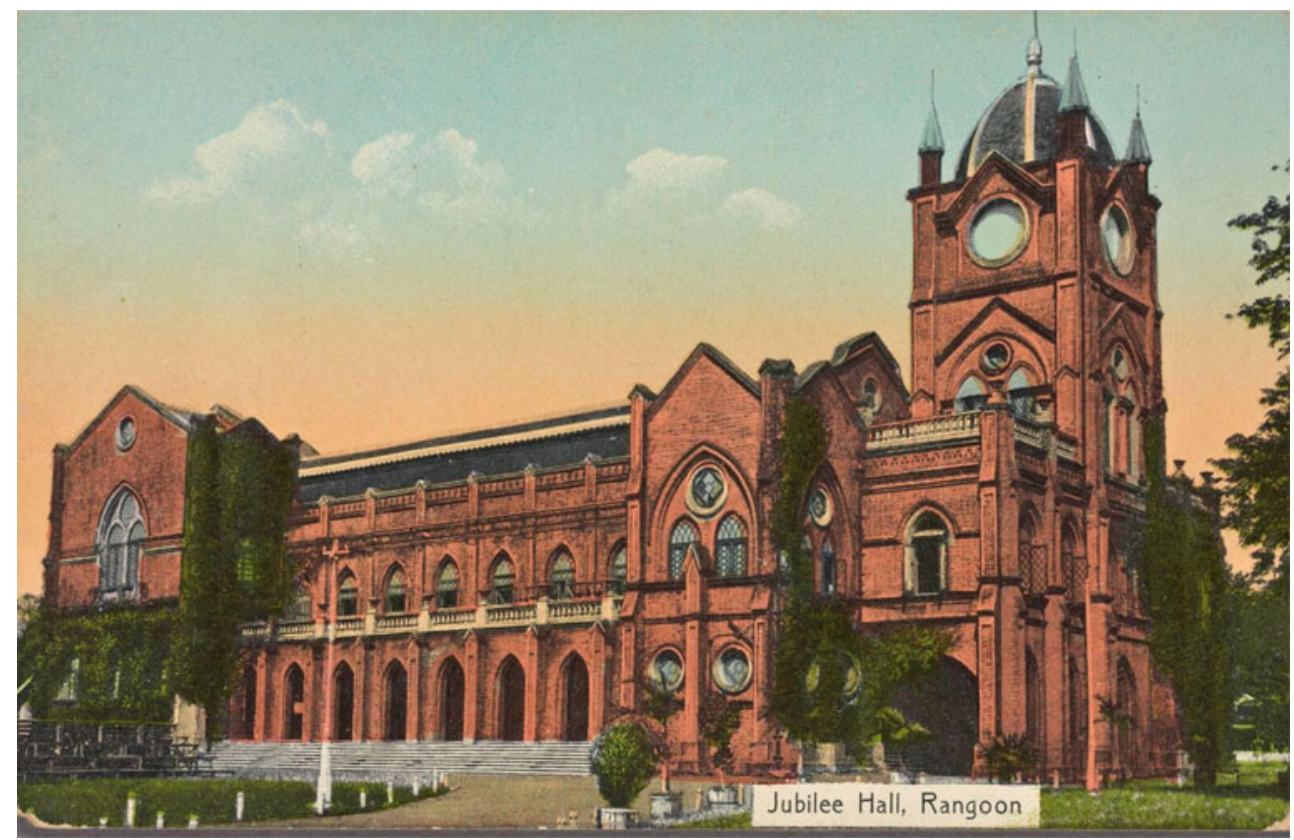

Figure 7. Jubilee Hall, Rangoon; postcard, 1910

Art and Picture Collection, New York Public Library Digital Collections; http://digitalcollections.nypl.org/items/c2630359-a048-1508-e040-e00a180613de (last accessed 28 Aug. 2017).

Perhaps most tellingly, the theatrical repertoire associated with Parsi theatre had no apparent influence on Burmese dramatic literature. On the British Museum list of about 140 dramas (pya-zat) published between 1873 and 1913, none of the titles refer to Indic or Islamic subjects that might show the influence of Parsi theatre. ${ }^{109}$ There are a few Rama stories, traceable to the long Burmese history of Ramayana performance. ${ }^{110}$ By contrast, Parsi theatre activity in Penang and Singapore prompted translations from Urdu into Malay of classics such as Indra sabha, Gul Bakawali, Laila Majnun and others. These works were adapted to the traditional Malay genres of hikayat and syair and published from lithographic presses in the later nineteenth century. Emergent forms such as the Minangkabau theatre deployed this repertoire, and by the early twentieth century these plots began to prevail in the wayang bangsawan. ${ }^{111}$

In the absence of other clues, it appears that the Parsi theatre in Burma flared, flickered, and then died out. The resilience of the Burmese performing arts was surely a major factor in minimising its impact. Before contact with the Parsi theatre, the Burmese classical arts flourished under court patronage, absorbing and nativising

109 Barnett, Catalogue, pp. 311-14. See also Maung Htin Aung, Burmese drama: A study, with translations, of Burmese plays (London: Oxford University Press, 1937), pp. 111-12; Hla Pe, Konmara, pp. 6-7. 110 U Thaw Kaung, 'The Ramayana drama in Myanmar', Journal of the Siam Society 90, 1 \& 2 (2002): 137-48.

111 Braginsky and Suvorova, 'New wave': 137-8. 


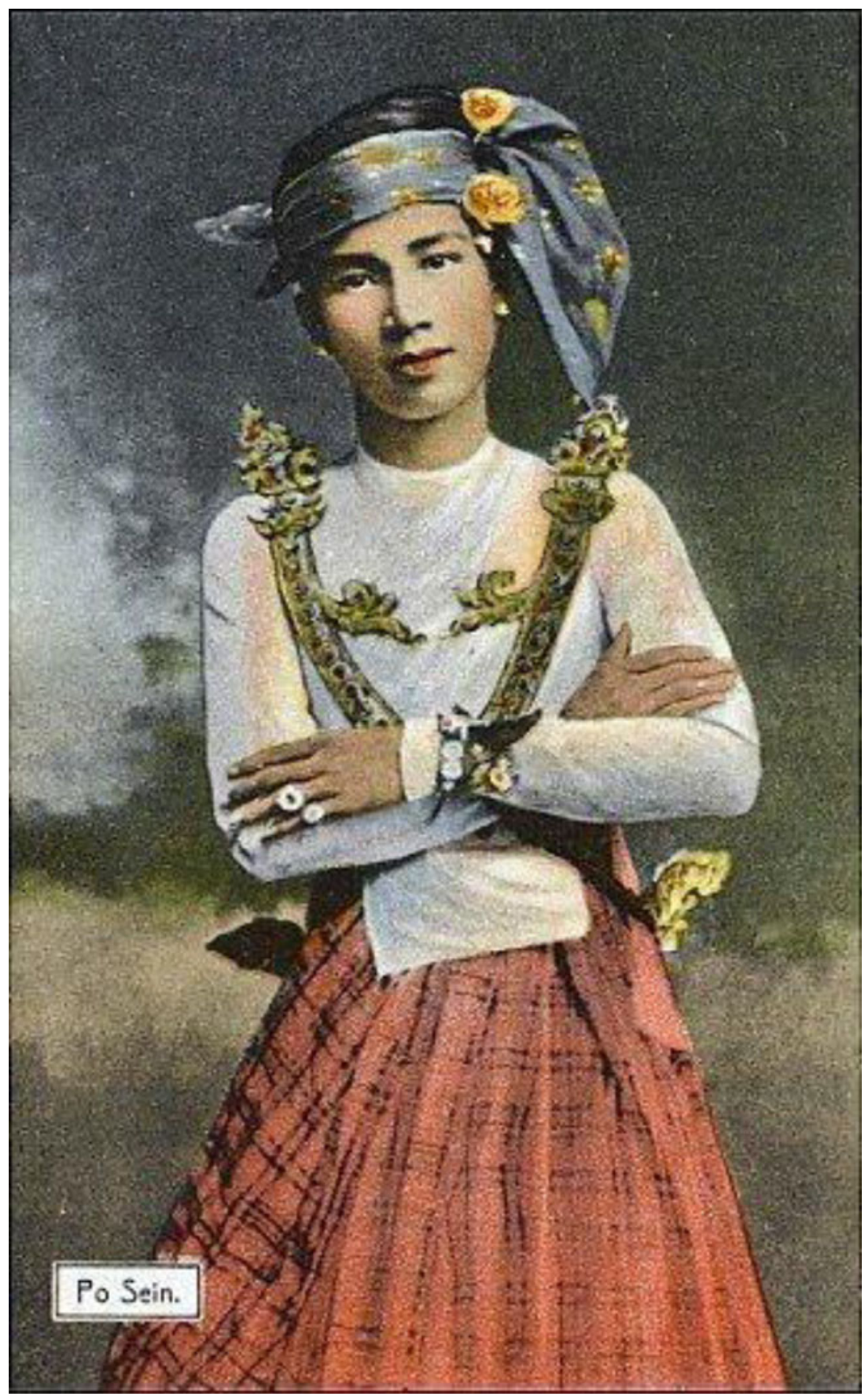

Figure 8. Po Sein; postcard, c.1910

Grenville Collins Postcard Collection, Wikimedia commons. 
foreign and ethnic influences. As the arts complex adapted to conditions under the British, its structures provided strong frames. New inputs did not overwrite them but were assimilated with little fundamental change. Theoretically, zat pwe could have emulated Parsi theatre in its heyday and incorporated aspects of its music and style, even while it retained its own integrity, but there is no basis for suggesting that it took this route. Burmese popular entertainment did not import the Indian manner, as it has done with the global culture of rap and hip-hop in recent times. ${ }^{112}$

In the final analysis, the harsh occupation of Burma, carried out by an alien class of British overlords and their Indian proxies, may have doomed the Parsi theatre to a marginal position. Indic civilisation was one of the principal fonts from which Burmese culture had sprung, but this did not diminish the humiliation and outrage of being forcibly subsumed as a province of British India. Burma had its own territorial aspirations and had been subjugating areas in eastern India as recently as the early nineteenth century. Konbaung kings conquered Arakan in 1785, installed a puppet ruler in Manipur in 1820, and invaded Assam in 1823 with their sights set on Bengal. ${ }^{113}$ It took three wars before the British took Upper Burma, and resistance to the British continued thereafter.

By the 1930s, the Burmese in Rangoon had mounted one of the strongest anticolonial nationalist movements in Asia. Whereas other port cities such as Penang became quite anglophilic and multiethnic, Burmese intellectuals to a large extent rejected cosmopolitanism, instead reviving older loyalties and making claims to being a culturally homogeneous nation. ${ }^{114}$ In the nationalist struggle, resentment against Indian migrant groups was rampant, directed often at middle-class Indians who were viewed as stooges of the Raj. Indians were physically driven out, and the contributions of Indians to colonial society were uprooted from historical discourse.

Importantly for the present inquiry, the reconstruction of a glorious past in Burma entailed the revival of the classical arts associated with the Konbaung court and Buddhist tradition. The pinnacle of development of theatre and drama was considered to have been reached during the 1870s; after that, decadence allegedly set in. ${ }^{115}$ Under the revolutionary socialist leader Ne Win (1962-1988), cultural politics ran towards nativism and xenophobia. The keepers of culture turned back nostalgically towards the era of monarchy. ${ }^{116}$ No place remained for the hybrid cultural forms of colonial modernity.

112 Ward Keeler, 'What's Burmese about Burmese rap?', American Ethnologist 36, 1 (2009): 2-19.

113 Lieberman, Strange parallels, p. 187.

114 Lewis, 'Print culture': 129-37.

115 According to Htin Aung, the pinnacle of Burmese drama was reached with the two nineteenthcentury dramatists, U Kyin U and U Pon Nya. The years 1878 to 1886 were the 'decadent period'. They coincided with the Burmese stage becoming 'a copy of the European stage' (Burmese drama, p. 147). After the British takeover, 'drama decayed' and never recovered (p. 111). Hla Pe advocates for the reputation of $\mathrm{U}$ Pok Ni, praising his 1879 play Konmara pya-zat. He too, however, sees a 'decline in literary merit' setting in thereafter, and characterises the post-1886 period as 'barren of imaginative literature of any quality' (Burma, p. 24).

116 One manifestation of the lingering attachment to King Thibaw is found in the large number of contemporary stage and puppet plays about his deposition (Diamond, 'Delicate balance': 109). This phenomenon began much earlier. Htin Aung reported in 1937 that '[in the aftermath of 1885] there was intense regret and the Burmese Crown, from which the past greatness of the nation had flowed, came to be looked upon with great sentimentality ... The drama therefore was used to present scenes of great splendour, in which court manners and customs were shown to an audience who ... knew their national court only from hearsay' (Burmese drama, p. 112). 